Article

\title{
Sustainability in the Case of Small Vegetable Farmers: A Matrix Approach
}

\author{
Ioan Sebastian Brumă ${ }^{1,2}$ (D), Simona-Roxana Ulman ${ }^{3, *}$, Cristina Cautisanu ${ }^{3, * \mathbb{D}}$, \\ Lucian Tanasă ${ }^{1,2, * \mathbb{D}}$ and Gabriel Vasile Hoha ${ }^{4}$ \\ 1 Romanian Academy, "Gh. Zane” Institute for Economic and Social Research, 700481 Iasi, Romania; \\ sebastianbruma1978@gmail.com \\ 2 Rural Development Research Platform Association, 707280 Letcani, Romania \\ 3 CERNESIM Environmental Research Center, Institute of Interdisciplinary Research, "Alexandru Ioan Cuza" \\ University of Iasi, 700505 Iasi, Romania \\ 4 Faculty of Food and Animal Sciences, "Ion Ionescu de la Brad" Iasi University of Life Sciences, \\ 700490 Iasi, Romania; gabihoha@uaiasi.ro \\ * Correspondence: simona.ulman@uaic.ro (S.-R.U.); cristina.cautisanu@uaic.ro (C.C.); \\ lucian.tanasa@gmail.com (L.T.)
}

check for updates

Citation: Brumă, I.S.; Ulman, S.-R.; Cautisanu, C.; Tanasă, L.; Hoha, G.V. Sustainability in the Case of Small Vegetable Farmers: A Matrix Approach. Sustainability 2021, 13, 10320. https://doi.org/10.3390/su131810320

Academic Editor: Florin Constantin Mihai

Received: 30 August 2021

Accepted: 13 September 2021

Published: 15 September 2021

Publisher's Note: MDPI stays neutral with regard to jurisdictional claims in published maps and institutional affiliations.

Copyright: (c) 2021 by the authors. Licensee MDPI, Basel, Switzerland. This article is an open access article distributed under the terms and conditions of the Creative Commons Attribution (CC BY) license (https:// creativecommons.org/licenses/by/ $4.0 /)$.

\begin{abstract}
Considering that sustainability is a relative concept, but also that this limitation could be avoided through continuous adaptation of the evaluation tools by taking into account the directions of change (such as time, space, application domain), the goal of the present study is to elaborate a matrix for measuring the level of sustainability for small vegetable farms. Thus, looking at what sustainability could represent under such circumstances, we divided its characteristics into four main dimensions (economic, social, environmental, cultural), while adding the private dimension. Inclusion of the private dimension may provide potential added value to this study, and thus enrich the general perspective of producers' capacity to meet the sustainability goals in their entrepreneurial activity. To quantify these five dimensions of the sustainability matrix, a questionnaire was built up and used as support for face-to-face interviews conducted at the level of the North-East Development Region of Romania. Our results showed associations between diverse components of the dimensions considered, revealing their synergy in farm activity, along with the occurrence of some differences in the levels of sustainability dimensions and sub-dimensions, which differ as a function of the specific types of vegetable production (conventional, ecologic, natural, mixed).
\end{abstract}

Keywords: sustainability matrix; economic; social; environmental; cultural; private dimensions; vegetable small farmers; conventional; organic; natural production system; North-East Region of Romania

\section{Introduction}

Sustainability represents one of the main concerns for the agricultural domain [1,2], related to the idea of sustainable agriculture [3] as a way of achieving some of the sustainable development goals [4]. Closely related to this, food sustainability is one of the concepts considered important to achieving global sustainable development, potentially improving the efficiency and sustainability of resource use, while simultaneously reducing natural resource damage and waste.

Local food supplies are generally considered more sustainable because they take into account all three dimensions of sustainability, while producing economic benefits, generating environmental positive effects, and creating a favorable social impact [5]. In addition, many studies found that consumers often perceive local foods as more sustainable than non-local foods. Still, (1) local foods are not necessarily more environmentally sustainable [6]; (2) social impacts are also highly relevant, because consumers prefer local foods to support regional farms [7,8]; (3) sustainability has become an arena of competition 
among companies. In the food sector, a diffuse perception of the unsustainability of "big food" $[9,10]$ has opened the way to a myriad of "local food" initiatives. The "local" has been frequently associated with sustainable and healthy production and consumption patterns [11,12], allowing "weak" actors in the system-in particular, farmers-to challenge "big food" with alternative principles, values, organizational patterns, and business models $[13,14]$.

In this context, some of the benefits of an organizational evaluation in terms of sustainability should be mentioned. At the company level, it may prove effective to explore best practices, benchmarks, critical points, and errors to avoid. At the consumer level, the comparative sustainability assessment can promote more informed choices, based on multiple criteria of economic, social, ethical, health, and environmental impact of food behavior. At the policy level, it can help better understand the synergies between configurations and the dynamics that integration may generate in relation to the desired policy goals. This type of assessment can assist decision-making and strategic planning throughout the entire policy cycle [15] (p. 4), [16] (p. 99). Comparative sustainable assessment could also be the basis for a "social contract" approach to corporate responsibility [14], as a possible way for providing a higher volume of public goods capable of increasing the total obtained income [17] (p. 275).

As an implication of the evolution in the development theory, a better understanding of the principal components of sustainable development in different areas of activity remains one of the major current issues, because, apparently, the principle of sustainable development is not sufficiently put into practice and also not sufficiently understood for a proper evaluation in different contexts. However, proponents of sustainable development differ in their perspectives on what is to be sustained, what is to be developed, and how to link the environment to the different dimensions of society [18] (p. 560). In this context, the definitional ambiguities concerning sustainable development are frequently mentioned [18-22], justifying the amount of work dedicated to developing quantitative indicators used for measurements (such as [1,23-34]).

Assessment of the sustainability of different farming systems is a challenging process including several steps, such as: identification of stakeholder groups, selection of experts, issues, and weights that illustrate the roughly similar influence of various aspects and sustainability dimensions [35-37]. In addition, the sector of agriculture is divided into different sub-sectors (as the one of vegetable production) characterized by specific features that, accordingly, require special attention. This extra element reveals the complexity of the evaluating process of agricultural sustainability and constitutes a premise for considering it of foremost significance for the authors of this paper.

A series of major arguments support the importance of measuring sustainability through developing a sustainability tool for the vegetable production system [19,31-33,38-48].

Firstly, sustainability represents a relative concept that fluctuates in terms of meaning, being determined by the evolution of a society as a whole. Moreover, as Gómez-Limón and Riesgo [31] (p. 3345) pointed out, moving on to a narrower area of analysis, that agricultural sustainability translates into "the ability of agricultural systems to satisfy different demands as times change". Hence, it is underlined the constant need of updating this concept based on the changes registered at societal level and in specific areas of analysis, such as the production of vegetables, in this case. Accordingly, what sustainability means must be specific to time and place [31] (p. 3345), and yet also specific to the topical domain of application [33]. The fact that sustainability represents a relative concept was considered as one of its limits, hindering its usefulness as a criterion for guiding the development process in different areas of interest [31] (p. 3345). This limit may be avoided through continuous adaptation of its evaluation tools, while taking into consideration the major directions of change, such as: time, space, and domain of application.

Secondly, although the major scope of a food system is to produce food commodities based on economic reasons, the producers also need to consider the effects of the environmental and social dimensions of their activities along the entire product life cycle [32,38-40]. 
Based on this evaluation, the directions of proper actions that answer to the desideratum of sustainability might be possibly formulated.

Thirdly, there is always room for improving the analysis of the sustainability phenomenon, as "thanks to Walras, Pareto or Nash, we will be convinced there are no ideal models of sustainability" [19] (p. 25).

Fourthly, a new reconfiguration in terms of food and health security, as a consequence of the new context imposed by the actual sanitary crisis, can be noticed. People tend to register a higher awareness on the importance of health in their life [41,42] and, consequently, become more health-oriented in terms of food [42-44]. In some countries, due to the crisis triggered by the COVID-19 pandemic, people started to purchase more fresh vegetables and food, both directly and online, from local producers/processors $[45,46]$. In the light of our new actual sanitary context and along with the fact that sustainability, through its objectives, represents a major goal in itself, always striving for improvement and adaptation in constantly changing contexts that in their turn, ask for new ways of analysis and measurement, a novel approach could be recommended for appreciating the sustainability of vegetable production systems. Similar approaches have been proposed by Gómez-Limón and Riesgo [31], Talukder et al. [1], Iocola et al. [47], and De Olde [48]. Each of them tried to respond as properly as possible to their analyzed context, necessarily to be taken into consideration when proposing such a tool; still, their application remains limited and necessarily adaptable to new contexts, as a function of other specific proposed goals.

Consequently, the main aim of this study is to run a diagnostic on sustainability for the vegetable production system, with focus on the North-East Development Region of Romania. Thus, we are looking to attain a clear image of what sustainability could represent in this area, dividing its main features into four main dimensions (economic, social, environmental, and cultural), while adding the private dimension. Although the first three dimensions are the most commonly ones in the approaches regarding sustainability, the dimension related to the cultural aspect is also not exactly new, it has been already met in various studies, such as those of Horlings [49], Axelsson et al. [50], Chiu [51], Scerri and James [52], Al Shamsi et al. [33], Peano et al. [53], the main justification being that culture supports ways of actions almost throughout, whether if refers to work, co-operation, labor division, environmental attitudes, and so on. Further on, we would like to discuss a new dimension, i.e., the private one, which we consider essential when, although "it is of the ensemble" [19] (p. 24), sustainability is put into practice by individual initiatives characterized by specific features that should not be neglected. Individualism, and not holism, as a principle of judgment, remains the distinctive feature of constructing and acceding to economic welfare [19] (p. 5), as the basis for the other dimensions of sustainability [27], without which neither social nor environmental dimensions could be supported in their process of attaining a sustainable path, their status representing "a consequence rather than a starting point" [19] (p. 24). Therefore, following Smith [54], the individual initiative is the main resort of bringing about transformation $[19,55,56]$. Consequently, our study firstly analyzes a specific type of this individual entrepreneurial initiative and, secondly, given the importance of the personal component in the development path of an individual initiative, also integrates among sustainability's dimensions the private one, characterized by personal peculiarities capable of enriching the ability to comprehend the whole perspective upon a sustainable activity.

While leaning on the founding principles for finding out what sustainability represents in the actual context of the analyzed area, i.e., the vegetables producers from the North-East Development Region of Romania, our added value is that of taking into consideration, as well, the private dimension, capable, in our opinion, to enrich the general perspective of producers' capacity to respond to sustainability goals in their entrepreneurial activity.

Starting from the overall context and the brief motivation of our research endeavor, on considering the major goal of our study, we shall outline the following objectives: 
1. Elaboration of an evaluation tool for analyzing the level of sustainability of the vegetable production system (i.e., a sustainability matrix for the vegetable production system, composed of dimensions, sub-dimensions, and components of each subdimension).

2. Measurement and analysis of the level of sustainability for the local vegetable producers from the North-East Development Region of Romania.

3. Comparison between the three (conventional, natural, ecological) types of agricultural production in terms of the levels of sustainability recorded.

The paper has been structured into four sections. Following the introductory section (Section 1) which contains the literature review on the concept of sustainability in agriculture and its main dimensions, Section 2 describes the methodology of constructing the proposed sustainability matrix for the vegetable production system, while Section 3 offers data and explains the methodology applied. The results obtained are presented in Section 4. Section 5 provides discussions and Section 6 draws the necessary conclusions.

\section{Methodology of Constructing a Sustainability Matrix for the Vegetable Production System}

The conceptual framework for evaluating the level of sustainability in a vegetable production system, depending on its five dimensions, is shown in Figure 1. Each dimension contains different appropriate sub-dimensions which are further detailed in the next part of the methodology section. Accordingly, the five dimensions represent the basis of our sustainability matrix, a potentially effective tool for evaluating the sustainability of small vegetable farmers, as detailed below: (1) the economic dimension, with its specific features in terms of tangibles, product, price, promotion, distribution, incomes; (2) the social dimension, containing sub-dimensions, such as education, health, workforce, good governance; (3) the environmental dimension, analyzed from the perspective of natural resources, energy resources, used practices, environmental concern: actions, climate change; (4) the cultural dimension, with its specific components in terms of labor, valorization of personal activity, environmental concern, perceptions; (5) the private dimension, with focus on personal wellbeing, farm activity, factors related to farm. The sustainability matrix was built according to the main results shown in specific studies, considered relevant for our objectives. Thus, the most important arguments for selecting each dimension, sub-dimension, and particular components were explained with reference to the main findings provided by literature in the sections concerning the introduction (geared toward the dimensions) and methodology (with focus on sub-dimensions and their components), in order to support for our approach.

\subsection{Composition of the Sustainability Matrix-Economic Dimension}

The economic dimension is composed of six sub-dimensions which include different specific components (Figure 2).

Firstly, tangibles-such as the total cultivated area of land, total area held in property, total leased area, total area cultivated with vegetables, total cultivated area of the current year compared to the previous year, animal holding, agricultural machinery and equipment, investments of the current year-represent the material basis for the agricultural activities that directly influence the economic results and other components of sustainability, as well [33]. The capital of the economic agents can be invested in goods with a utilization period longer than one year, defined as tangible assets, and representing the goods on which a real legal right can be exerted. They may include: freehold lands and land improvements, constructions, technical installations, machinery, machines or cars and furniture, advances given to the providers of tangible assets and tangible assets in progress [57]. Agricultural business requires significant support for the processes of reproduction of the resource potential, the main place being held by the state of resources of enterprises, in particular, by fixed assets [58] that need to be included in a matrix for evaluating the level of sustainability of a small vegetable farm. 


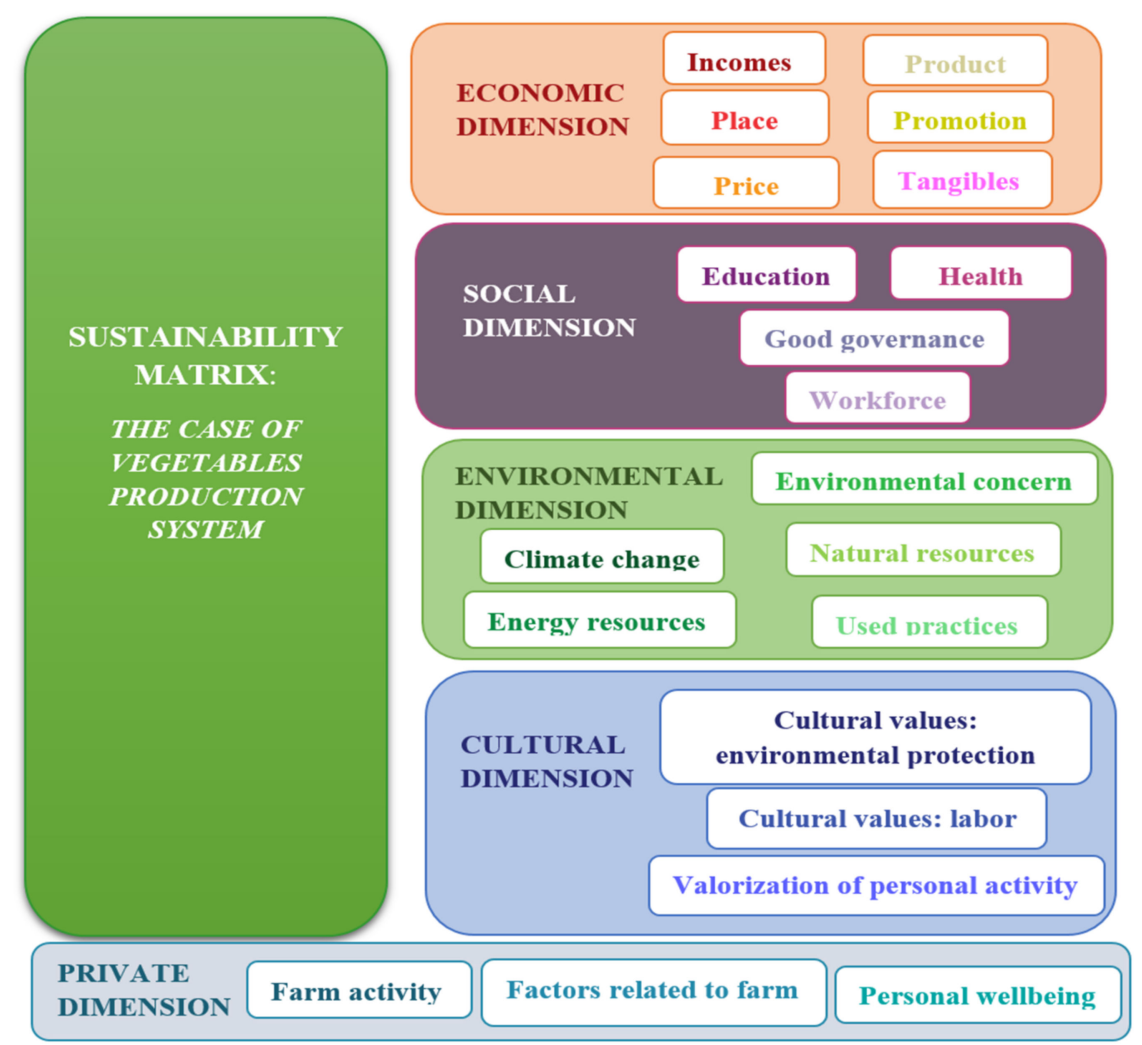

Figure 1. Sustainability matrix—dimensions and sub-dimensions.

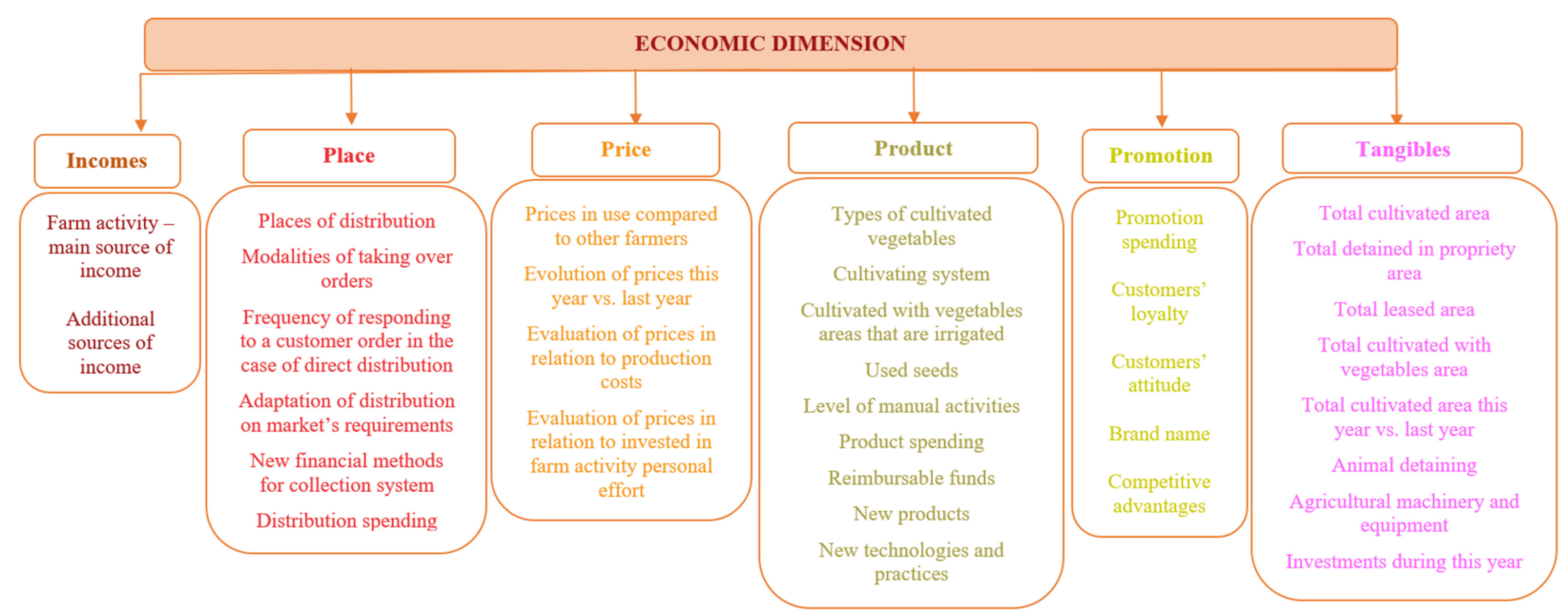

Figure 2. Sustainability matrix-Economic dimension and sub-dimensions.

Secondly, as part of the marketing mix (apart from price, place, promotion), as representing an important strategy consisting of different marketing tools used for selling on the market [59], the generically-called product, in our economic dimension of sustainability, is related to the types of cultivated vegetables, cultivating systems, areas cultivated with vegetables (usually, an irrigated area), used seeds [60], the level of manual activities, how products are capitalized, and also producers' availability to integrate new technologies, to access new reimbursable funds, to diversify/extend the product portfolio of their vegetable production. All its components are known to significantly influence the economic dimension of the entire activity of the small vegetable farmers [61,62].

Thirdly, the price of vegetables provides an economic perspective on producers' individual activity, which differentiates them on the market [63], whereas its evolution, 
closely related to market fluctuations, outlines a real and pragmatic image of the economic dimension. Its role is extremely important, as widely highlighted in different studies and, as mentioned by Binswanger [64] (p. 231), the literature shows convincingly that the long-run response of agriculture is quite ample: higher prices will slow migration out of rural areas and increased investment in agriculture. This is the second component of the marketing mix that makes the subject of our analysis in terms of active prices compared to other farmers, evolution of prices for the current year vs. previous year, evaluation of prices in relation to production costs and investments in farm activity and personal effort.

Fourthly, besides the issues related to product and price, producers should pay attention to all specific phases of taking a buying decision (problem recognition, information search, purchase, post-purchase evaluation) and thus run an effective promotional campaign for each stage and detail the strategic marketing plan without overlooking important elements of the buying decision process [65-67]. Accordingly, the promotion of the small vegetable production represents an activity that implies specific actions, namely promotion expenses, customers' loyalty, study of customers' attitude [68,69], brand name, and the ability to benefit from competitive advantages. These components are integrated into the economic dimension for a proper evaluation of the sustainability of a vegetable farm.

Fifthly, the distribution (place) in the case of vegetables, given the specificity of the distribution chain in terms of adaptation to customers' needs and requirements [70-72], represents a synergy between the economic and environmental dimensions, especially when it comes to short food supply chains [73]. Moreover, this requirement of adaptation has become more stringent in the current circumstances, as emphasized in different studies, such as those of Brumă et al. [44] or Butu et al. [45]. Consequently, for this sub-dimension, we have considered as fundamental the following aspects: places of distribution, systems of taking orders, frequency of replying to a customer order in the case of direct distribution, adaptation of distribution to market's requirements, new financial methods for the collection system, distribution expenses.

Sixthly, incomes are a significant part of the economic dimension, closely linked to the possibility of putting into practice, at a satisfactory level, other dimensions of sustainability. Accordingly, on one hand, income ensures the financial basis for a sustainable activity [74] and, on the other, it represents an important source of work satisfaction, able to create a synergy with the private dimension. In line with previous studies, the findings of Mayraz et al. [75] confirm the importance of relative income comparisons to subjective well-being. In addition, the relative income (social as well as temporal) is more important for life satisfaction than the absolute income [76]. With these assumptions in mind, the component of income for small vegetable producers is analyzed in terms of farm activity as their main source of income, besides other additional sources of income.

\subsection{Composition of the Sustainability Matrix —Social Dimension}

The social dimension is composed of four sub-dimensions, formed, in their turn, of different specific components (Figure 3).

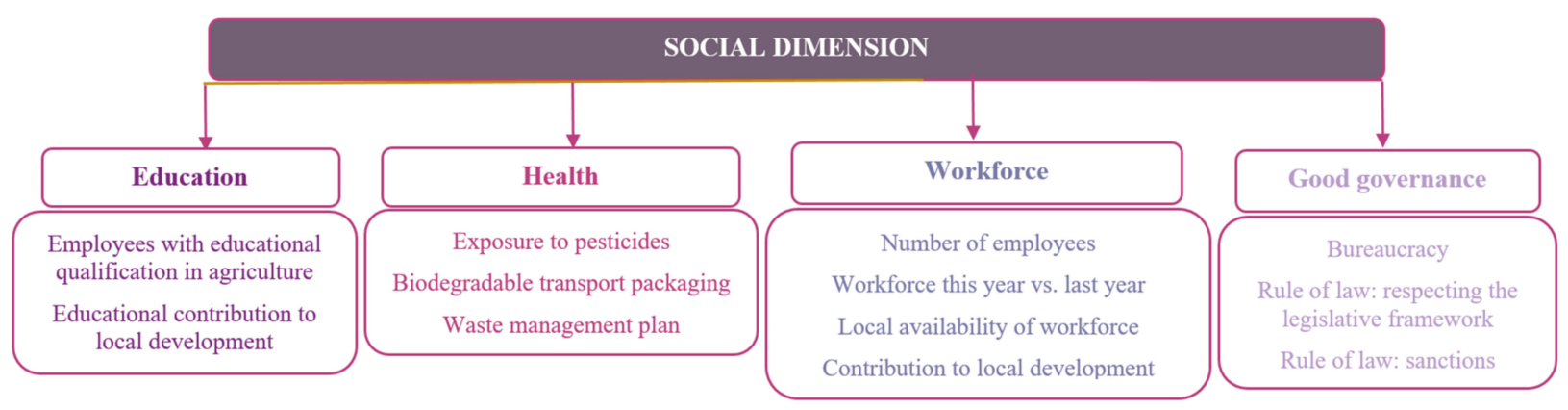

Figure 3. Sustainability matrix-Social dimension and sub-dimensions. 
Firstly, education, as one of the milestones of development, representing in itself an increasingly valued asset within all societies [77], usually a must-have among the most important components of the social (human) wellbeing (see $[27,78]$ ) and with its main scope of forming and improving the competences of the labor force, is here analyzed from the perspective of the educationally qualified employees in agriculture, and in view of the educational contribution to the local development in the production activity.

Secondly, health is a component closely linked to the individual capabilities that, apart from the aspects regarding income and education [79] (p. 9), is frequently included among the components of sustainability's social dimension (see again $[27,78]$ ). The absence of health is connected to major negative issues, such as vulnerability, risk, powerlessness, lack of voice, and low environmental concern [80]. Accordingly, in the here proposed sustainability matrix, health has been integrated among the four components of this dimension, being evaluated from the perspective of pesticide exposure, biodegradable transport packaging, and waste management plan.

Thirdly, workforce is an extremely important business asset, considered by GómezLimón and Riesgo [31] as one of the most significant social indicators in the agricultural sector. In our work, it was included as a tool for measuring sustainability in terms of number of employees, comparison between the current year and previous year, local availability, and capacity of contributing to local development.

Good governance is on the list of the decisive points in the process of development [81], showing positive changes in accordance with the six key principles [82] (p. 138) referring to the following aspects: (1) voice and accountability of the citizens of a country; (2) political stability; (3) government effectiveness; (4) regulatory quality; (5) rule of law; (6) corruption $[27,83]$. In our sustainability matrix, it is evaluated from the perspective of bureaucracy in terms of its impact on farm activity, rule of law: respecting the legislative framework by most local producers and rule of law, applying sanctions considered essential for the type of activity analyzed in the present study in terms of frequency and local context (i.e., vegetable production).

\subsection{Composition of the Sustainability Matrix-Environmental Dimension}

The environmental dimension is composed of five sub-dimensions formed, in their turn, of different specific components (Figure 4).

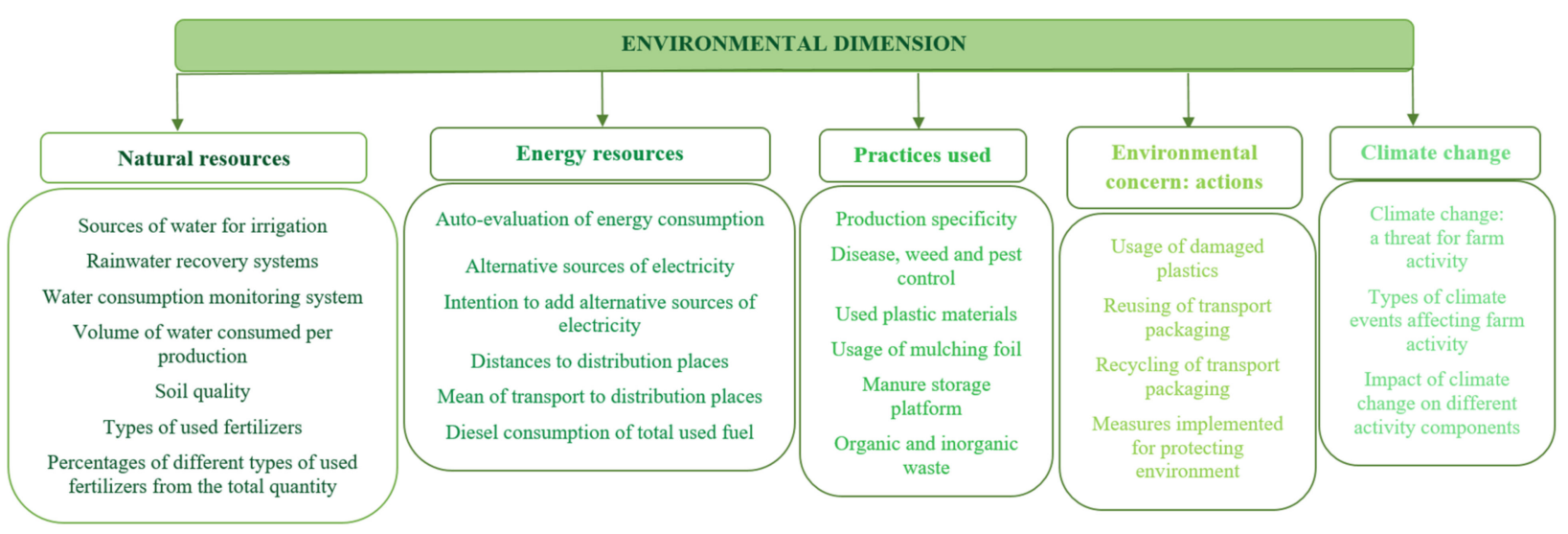

Figure 4. Sustainability matrix-Environmental dimension and sub-dimensions.

Firstly, natural resources have been given considerable global attention in the literature, due to their broad economic implications [1,84-87], while humans' extensive consumption of them has been constantly exercising enormous environmental pressure [88,89]. Consequently, as an important component of the environmental dimension, in the present proposed matrix, sustainability of natural resources involved in the vegetable production is evaluated in terms of sources of water for irrigation, rainwater recovery systems, water consumption monitoring system, volume of water consumed [31] per production, soil 
quality, types of fertilizers used, and percentages of different types of used fertilizers out of the total quantity.

Secondly, energy resources that pervade all sectors of society, from economics, labor, environment, international relations to personal lives regarding housing, food, health, etc. [90], are therefore fundamental to social development [91]. In this case (vegetable producers), they are observed from the perspective of auto-evaluation of energy consumption, alternative sources of electricity, intention of adding alternative sources of electricity, distances to distribution places, means of transport to distribution places, diesel consumption of total used fuel.

Thirdly, practices carried out in agricultural production are generally known as contributing to environmental pollution, which is further affecting food security, human health, and climate, thus imposing the need to shift from 'unclean' practices to sustainable ones [92]. They are integrated into our environmental dimension of sustainability with focus on production specificity, disease, weed and pest control, used plastics, usage of mulch foil, manure storage platform, and organic and inorganic waste.

Fourthly, environmental concern represents a collocation usually met in the literature dedicated to environmental degradation [65,93-100], having been acknowledged as one of the initial steps in the process of environmental protection, addressing changes in people's behaviors [101]. It can be analyzed from different points of view, such as usage of damaged plastics, transport packaging reuse and recycling, and measures taken for environmental protection.

Fifthly, climate change is the last component included in the suggested sustainability matrix for small vegetable producers, integrating perceptions on climate change as a threat for farm activity, types of climate events affecting farm activity, and impact of climate change on different activity components. As mentioned in FAO's Work on Climate Change United Nations Climate Change Conference in 2016, climate change is profoundly impacting the conditions in which agricultural activities are conducted, no other sector being more sensitive to climate change than agriculture [34] (p. 10). It is clearly explained that, in every region of the world, plants, animals, and ecosystems are adapted to the prevailing climatic conditions. When these conditions change, even moderately, plants and animals are impacted, some becoming less productive, or even disappear [34] (p. 3).

\subsection{Composition of the Sustainability Matrix - Cultural Dimension}

The cultural dimension is composed of three sub-dimensions formed, in their turn, of different specific components (Figure 5).

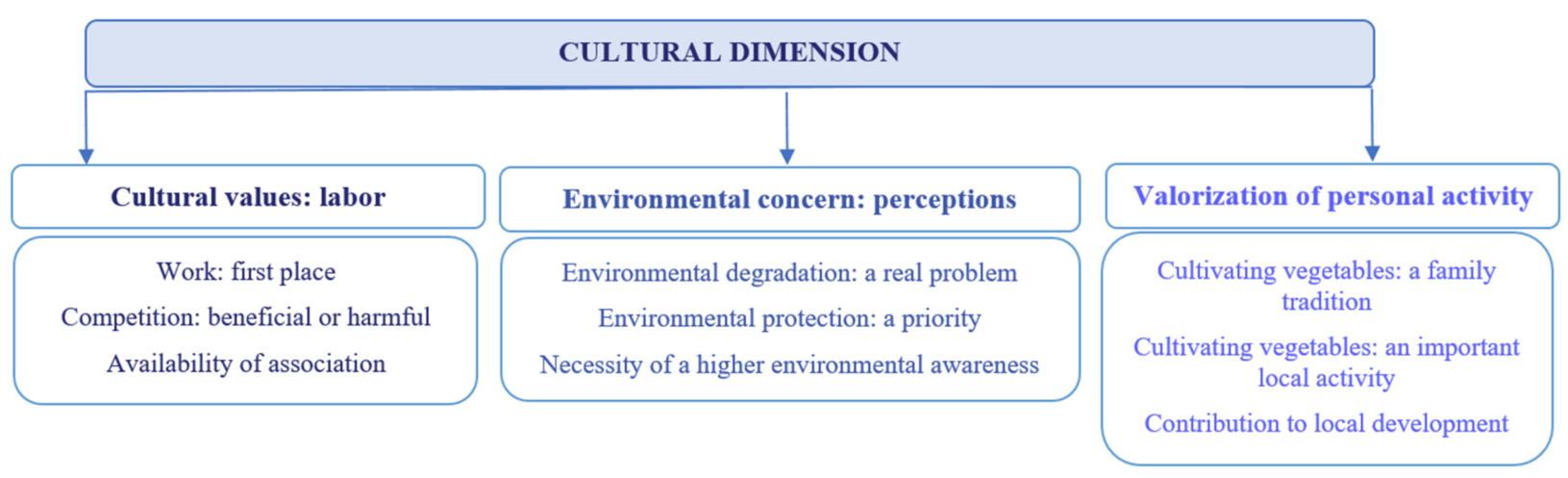

Figure 5. Sustainability matrix-Cultural dimension and sub-dimensions.

Firstly, labor, another important factor influencing the state of wellbeing and closely connected to education is, in the words of Adam Smith [54], the principal value creator. It represents an essential component of the cultural dimension, revealing individual work capacity $[63,102]$. In our study, it is analyzed from the perspective of work seen holding or not the first place. This component highlights the availability of individuals for association 
and for both ensuring the resilience of an agricultural system $[1,35,103]$ and its competitiveness [104]. The specific features, in terms of association and competition, are verified from respondents' perspective upon them, i.e., competition: beneficial or harmful, and availability of association.

Secondly, the component regarding the valorization of personal activity is considered as formed of three components, i.e., cultivating vegetables; a family tradition to grow vegetables; an important local activity, and contribution to the local development, all of them based on cultural specificities that emphasize capitalization of the cultural heritage, besides family tradition to grow vegetables [60], which thus reveals the capacity of maintaining and perpetuating specific local traditions, while also contributing to local development $[45,105]$.

Thirdly, environmental concern, defined as "the degree to which people are aware of environmental problems and support efforts to solve them and/or indicate a willingness to contribute personally to their solution" [106] (p. 485), is integrated into our cultural dimension from the viewpoint of the perceptions on environmental degradation: a real problem, environmental protection: a priority, and the necessity of a higher environmental awareness. Currently, the challenges of climate change [34,107] and in response to it, the difficulties faced by environmental protection [16] represent central pillars of the present agricultural systems.

\subsection{Composition of the Sustainability Matrix-Private Dimension}

The private dimension is composed of three sub-dimensions, in turn formed of different specific components (Figure 6).

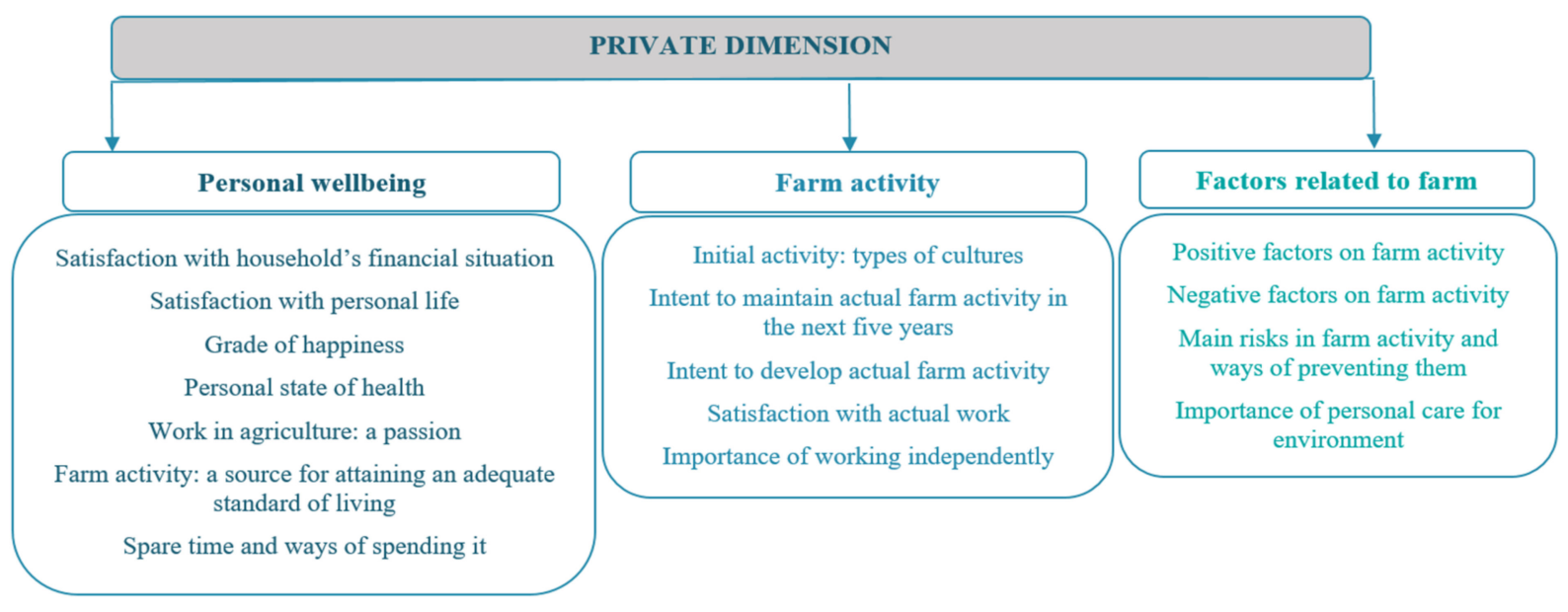

Figure 6. Sustainability matrix-Private dimension and sub-dimensions.

Firstly, personal wellbeing, intuitively understood as "how we are doing" as individuals [107] (p. 1), can be regarded as life satisfaction based on individuals' perception of their health, happiness, and sense of purpose [108]. It is closely related to work satisfaction in terms of both financial and personal life perspectives [1]. Additionally, there is an increasingly widespread belief to put wellbeing at the heart of a company's people agenda [107] (p. 4) to which an integrative approach is necessary. Accordingly, it is generally accepted that the extent of happiness and the personal state of health [14], along with the passion for work that ensures an adequate standard of living [109], represent significant determinant factors of one's outputs, therefore highly contributing to the sustainability of each effort. Thus, this important constituent of life, namely personal wellbeing, was integrated into our approach, being intended to observe individual's satisfaction with household's financial situation, satisfaction with personal life, degree of happiness, personal state of health, work in agriculture: hobby, farm activity: a source for achieving an adequate standard of living, spare time, and ways of spending it. 
Secondly, farm activity, in terms of initial activity (types of crops, intent to maintain the current farm activity for the next five years, intent to develop the current farm activity, satisfaction with current work, importance of working independently), is directly influenced by work, in general, and by the satisfaction with the obtained results [110]. These personal peculiarities of farm activity constituted a strong argument for their inclusion in our sustainability matrix, in the private dimension. Moreover, maintaining the farm activity and its development, while working independently, are strong pillars of sustainability.

In addition to these specificities of farm activity, for completing the private dimension, we have included in our matrix other factors related to farm, such as the positive and negative factors on farm activity [111,112], main risks in farm activity and ways of preventing them $[60,113]$, and the importance of personal care for the environment $[65,114]$.

\section{Materials and Methods}

To quantify the five dimensions of the sustainability matrix for the vegetable production system, a questionnaire was elaborated, and used as support for 30 face-to-face interviews conducted at the level of the North-East Development Region of Romania. The interviewed farmers were selected using the snowflake method. An important support for their identification was provided by the specific governmental structures from the NorthEast Development Region of Romania (County Agriculture Directorates). The vegetable farms considered in the study are divided into 4 distinct categories: (1) conventional farms, with a classical production system based on specific agriculture technologies adequate to each vegetable species, utilizing chemical inputs, (2) ecological farms, with an ecologically certified production system observing the specific legislative framework, (3) natural farms, with an eco-friendly production system, with no chemical but only natural inputs, yet not developing an ecologically certified production, (4) mixed farms, using different agriculture production technologies, both conventional, and ecological and natural practices.

The area taken into consideration in our study (i.e., The North East Region of Romania) is characterized by: (1) a significant vegetable potential (the cultivated agricultural area amounted to 42,526 hectares in 2019) [115]; (2) tradition in growing vegetables (continued from generation to generation within the Lipoven communities; native rural communities located along the main rivers of the region-Siret, Prut, Suceava, Bistrița-downstream from Piatra-Neamț town up to Bacău city); (3) the existence of some vegetable basins or micro-zones located across all six counties of the region [116]; (4) a high potential for conventional, natural, and ecological production systems for vegetables [117].

The questionnaire was transferred to a Google Form format, the data being collected between 4 April and 7 May 2021, by the TAWI methodology (Tablet Assisted Web Interview). This methodology was applied due to its unique advantages not assured by other methods (e.g., Input, PAPI, CATI, Online) [118], namely: (1) a better research organization, once all data is gathered in one single database without manual input; (2) no input required, so that the time needed for data processing can be cut down; (3) field status provided in real-time; (4) simplified operator's work because the device (i.e., tablet) is easy to carry and manipulate; (5) respondents become more interested and, therefore, more willing to respond.

The questionnaire is structured into six sections, one for each of the five dimensions and one referring to aspects related to the socio-demographic characteristics of the respondents, as presented in Table 1. Furthermore, the table includes a column that specifies the notations of the variables corresponding to the sub-dimensions considered. These notations will be used for the rest of the paper. 
Table 1. Questionnaire structure.

\begin{tabular}{|c|c|c|}
\hline Section & Sub-Dimension (Number of Questions) & Variable Notation \\
\hline Economic & $\begin{array}{c}\text { Incomes (3) } \\
\text { Place (29) } \\
\text { Price (4) } \\
\text { Product (22) } \\
\text { Promotion (16) } \\
\text { Tangibles (15) }\end{array}$ & $\begin{array}{l}\text { ec_incomes } \\
\text { ec_place } \\
\text { ec_price } \\
\text { ec_product } \\
\text { ec_promotion } \\
\text { ec_tangibles }\end{array}$ \\
\hline Social & $\begin{array}{c}\text { Education (2) } \\
\text { Good governance (4) } \\
\text { Health (6) } \\
\text { Workforce (9) }\end{array}$ & $\begin{array}{l}\text { soc_education } \\
\text { soc_good_governance } \\
\text { soc_health } \\
\text { soc_workforce }\end{array}$ \\
\hline Environmental & $\begin{array}{c}\text { Climate change (20) } \\
\text { Energy resources (10) } \\
\text { Environmental concern: actions (4) } \\
\text { Natural resources (19) } \\
\text { Used practices (21) }\end{array}$ & $\begin{array}{c}\text { env_climate_change } \\
\text { env_energy_resources } \\
\text { env_environmental_concern } \\
\text { env_natural_resources } \\
\text { env_used_practices }\end{array}$ \\
\hline Cultural & $\begin{array}{l}\text { Cultural values: labor (3) } \\
\text { Environmental concern: perceptions (4) } \\
\text { Valorization of personal activity (4) }\end{array}$ & $\begin{array}{c}\text { cult_labor } \\
\text { cult_environmental_concern } \\
\text { cult_valorization_of_personal_activity }\end{array}$ \\
\hline Private & $\begin{array}{c}\text { Personal wellbeing (9) } \\
\text { Farm activity (17) } \\
\text { Factors related to farm activity (17) }\end{array}$ & $\begin{array}{c}\text { priv_factors_related_to_farm_activity } \\
\text { priv_farm_activity } \\
\text { priv_personal_wellbeing }\end{array}$ \\
\hline Socio-demographic & $\begin{array}{c}\text { Age } \\
\text { Gender } \\
\text { Educational level }\end{array}$ & $\begin{array}{c}\text { Age } \\
\text { Gender } \\
\text { Educational attainment }\end{array}$ \\
\hline
\end{tabular}

A detailed presentation of the questionnaire is provided in the table listed in Appendix A, Table A1. For each of the sections, the table specifies the questions included in the subdimensions and the scales used to measure the responses offered to them.

In general, we used closed questions with a specific number of elements included in the scale, e.g., (1-3), (1-5), (1-10). However, in some cases, we also used open questions to get more information about various aspects related to respondents' business. The answers to these questions were subsequently coded, to make possible their utilization in the construction of the sustainability matrix.

For each sub-dimension, three levels of sustainability were considered: low, medium, and high. These levels were defined for each respondent based on the answers to the questions regarding each sub-dimension, as follows: responses in the lower part of the scale indicated a low level of sustainability, the ones in the medium part meant a medium level of sustainability, while the ones in the higher part referred to a high level of sustainability. The detailed recoding procedure for each scale is presented in the table from Appendix A, Table A2. The final values for each sub-dimension were obtained as the average of the recoded responses to the questions referring to it, and approximately close to the value of one of the codes for low (1), medium (2) and high level (3), respectively. The same procedure was used for determining the values of the five dimensions, based on the sub-dimensions included in them.

For analyzing the sustainability of small vegetable farmers, based on the five dimensions of the sustainability matrix (i.e., economic, social, environmental, cultural, and private), the following three steps were established: (1) running a descriptive analysis of the respondents, considering their socio-demographic characteristics (i.e., gender, age, and educational attainment); (2) applying the Multiple Correspondence Analysis (MCA) to identify the associations between the dimensions/sub-dimensions considered for describing the levels of sustainability for farmers; (3) building graphic representations (radars) both for the average values of the $30 \mathrm{farms}$ included in the analysis and for each of the 
four types of production systems under analysis (i.e., conventional, natural, ecological, and mixed), in order to evidence any possible differences, in terms of sustainability, among farmers, as a function of the production system used. Analysis was performed using IBM SPSS Statistics (version 26) and Tableau Public (version 10.3).

Multiple Correspondence Analysis (MCA), an extension of Correspondence Analysis (CA), is used to analyze the pattern of relationships of several categorical dependent variables. Also, it can be considered as a generalization of Principal Component Analysis (PCA), when the variables to be analyzed are qualitative instead of quantitative [119]. MCA aims at identifying a group of respondents with similar profile of their answers to the questions of a survey, and also the associations between the categorical variables. In $\mathrm{MCA}$, the categories of variables may be divided into active (i.e., contribute directly to the formation of the factors), and additional or illustrative (i.e., do not contribute to the creation of factors but, due to their position along the factorial axes, they play an important part in improving and enhancing their interpretation). Once the factors identified, both the active and supplementary category variables can be represented as dots projected into factorial spaces, orthogonally to each other. In order to interpret the graphs, the following rules apply: (1) if two or more categories of the same variable appear close to each other, this means that their distribution is similar; (2) if two neighboring categories belong to different variables, this means that the frequency present in the cell at the intersection between row and column is much higher than it would be if the categories were independent. Generally speaking, it may be asserted that farther a dot is from the origin of an axis, the greater the contribution it makes to the formation of the axis itself; furthermore, the greater is the proximity between two category-variables, the greater their interdependence [120].

\section{Results}

\subsection{Descriptive Analysis}

In terms of gender, our respondents are represented by 20 males and 10 females with ages ranging from 18 to 64 years. The largest group occurs in the 24-34 age range, representing $36.66 \%$ of the respondents. The age groups from the extremities (i.e., 18 to 24 years of age and 55 to 64 years of age) registered the same lowest frequency $(13.33 \%)$. In terms of educational level, $63.33 \%$ of the respondents have higher education and $42.1 \%$ of them also have Master's or PhD studies (Figure 7).
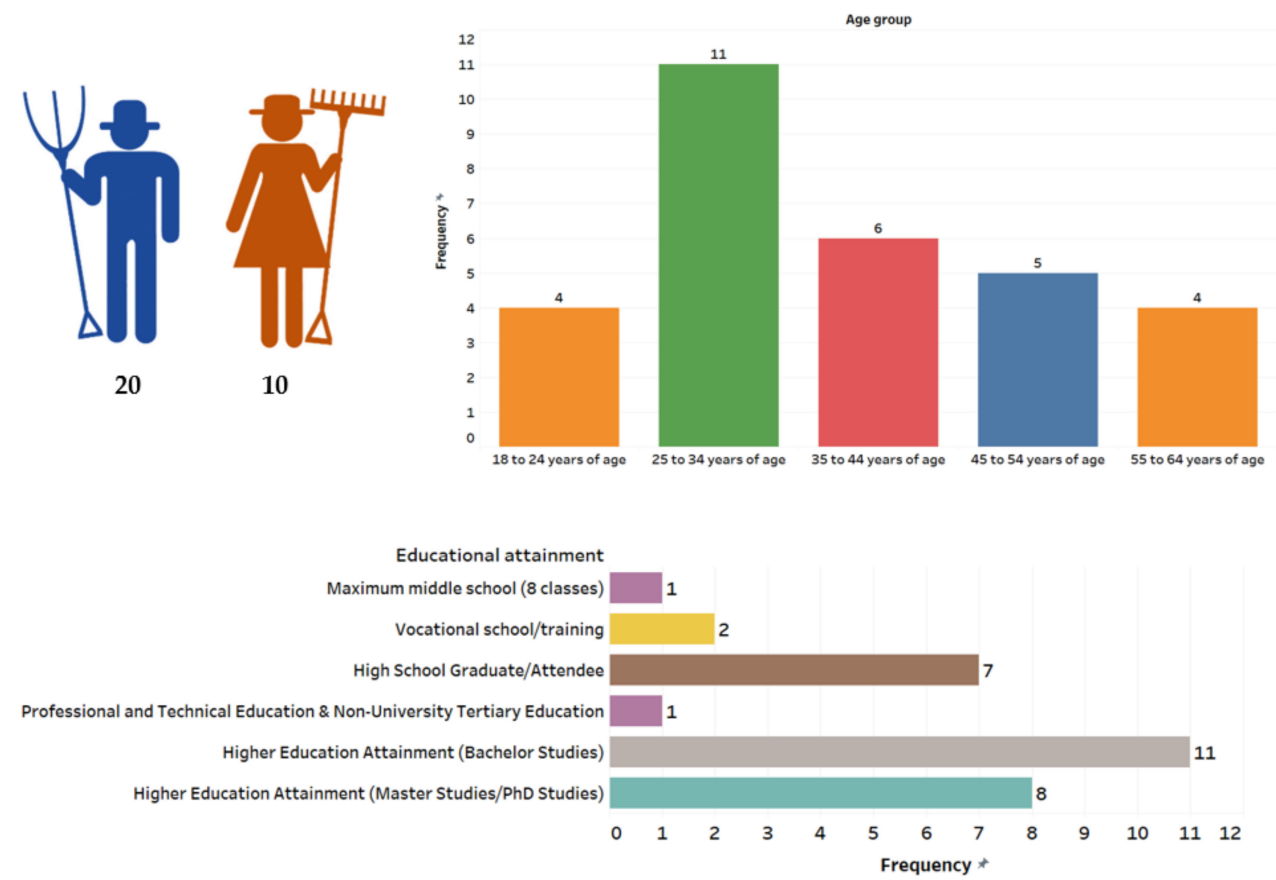

Figure 7. Main socio-demographic characteristics (age, gender, and educational attainment). 
Considering the descriptive statistics regarding the variables used (Table 2) for measuring the components of the sustainability matrix, we can observe that, if at the general level of the five dimensions their values vary from 1 to 3 , expressing the three levels of sustainability, the situation is different in the case of sub-dimensions.

Table 2. Descriptive statistics of the dimensions and sub-dimensions of the sustainability matrix.

\begin{tabular}{|c|c|c|c|c|c|c|}
\hline Dimension/Sub-Dimension & $\mathbf{N}$ & Minimum & Maximum & Median & Mean & SD \\
\hline Economic & 30 & 1 & 3 & 2 & 1.93 & 0.25 \\
\hline ec_incomes & 30 & 1 & 3 & 2 & 2.03 & 0.41 \\
\hline ec_place & 30 & 1 & 2 & 2 & 1.63 & 0.49 \\
\hline ec_price & 30 & 1 & 3 & 2 & 2.00 & 0.52 \\
\hline ec_product & 30 & 1 & 3 & 2 & 1.93 & 0.45 \\
\hline ec_promotion & 30 & 1 & 3 & 2 & 2.20 & 0.76 \\
\hline ec_tangibles & 30 & 1 & 2 & 2 & 1.87 & 0.34 \\
\hline Social & 30 & 1 & 3 & 2 & 1.76 & 0.43 \\
\hline soc_education & 30 & 1 & 3 & 2 & 1.77 & 0.67 \\
\hline soc_good_governance & 30 & 1 & 2 & 2 & 1.60 & 0.49 \\
\hline soc_health & 30 & 1 & 2 & 2 & 1.67 & 0.47 \\
\hline soc_workforce & 30 & 1 & 2 & 2 & 1.60 & 0.49 \\
\hline Environmental & 30 & 1 & 3 & 2 & 2.03 & 0.18 \\
\hline env_climate_change & 30 & 1 & 3 & 2 & 2.10 & 0.54 \\
\hline env_energy_resources & 30 & 2 & 3 & 2 & 2.10 & 0.30 \\
\hline env_environmental_concern & 30 & 2 & 3 & 2 & 1.90 & 0.40 \\
\hline env_natural_resources & 30 & 2 & 2 & 2 & 2.00 & 0.01 \\
\hline env_used_practices & 30 & 2 & 3 & 2 & 2.27 & 0.45 \\
\hline Cultural & 30 & 1 & 3 & 2 & 2.30 & 0.46 \\
\hline cult_environmental_concern & 30 & 1 & 3 & 2 & 2.27 & 0.45 \\
\hline cult_labor & 30 & 1 & 3 & 2 & 2.43 & 0.56 \\
\hline cult_valorization_of_personal_activity & 30 & 1 & 3 & 2 & 1.93 & 0.64 \\
\hline Private & 30 & 1 & 3 & 2 & 2.00 & 0.01 \\
\hline priv_factors_related_to_farm_activity & 30 & 1 & 2 & 2 & 1.93 & 0.25 \\
\hline priv_farm_activity & 30 & 2 & 3 & 2 & 2.37 & 0.49 \\
\hline priv_personal_wellbeing & 30 & 2 & 3 & 2 & 2.03 & 0.18 \\
\hline
\end{tabular}

For instance, in the economic and cultural sub-dimensions, all the three levels of sustainability were identified. On the contrary, in the social dimension, for the majority of sub-dimensions, respondents did not report a high level of sustainability. In addition, in many of the sub-dimensions corresponding to the environmental and private dimensions, the low level of sustainability was not identified among the respondents.

\subsection{Multiple Correspondence Analysis (MCA)}

MCA is a method of multivariate analysis that can be applied in the study of the associations between categorical variables. In the graphic plotted in Figure 8, the three levels of each variable were considered, namely low level $-\mathrm{l}$, medium level $-\mathrm{m}$, and high level- $h$, representing the sub-dimensions selected for evaluating each dimension of sustainability. Since the component of natural resources from the environmental dimension records zero variance, we excluded it from the MCA analysis. Each sub-dimension includes, in turn, several sub-components, as shown in the methodology section. Considering that our variables are categorical ones, we used the median value as the appropriate measure of central tendency, for establishing the specific level of each respondent regarding the analyzed sub-dimensions. 


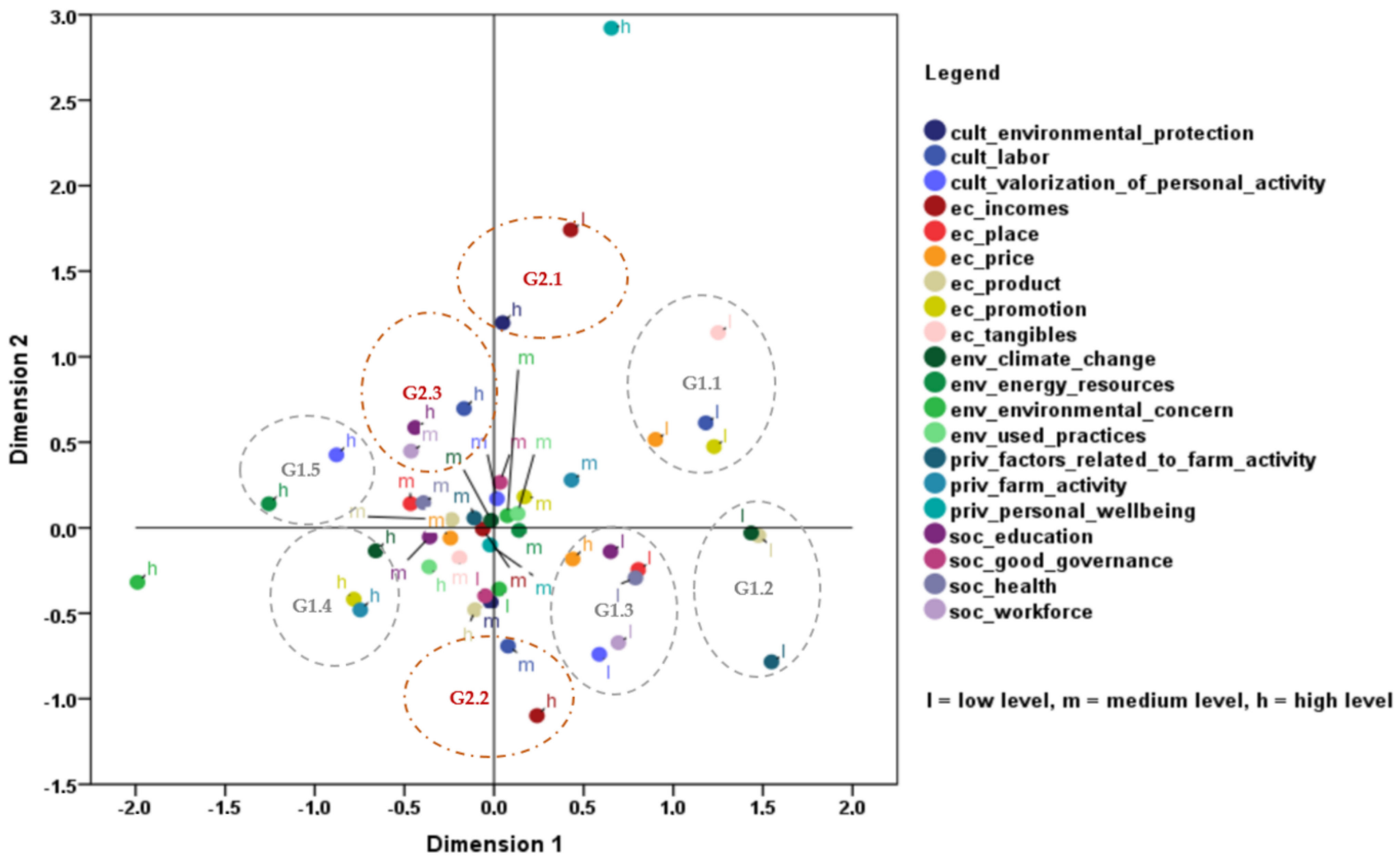

Figure 8. Associations among the sub-dimensions of the sustainability matrix.

For most of the sub-dimensions considered, the medium level appears in the center of the graphic representation, close to the intersection between the Ox axis (Dimension 1) and Oy axis (Dimension 2), showing insignificant associations between them (intersection points situated in the [0-0.5] interval). For the other two levels of the variables (i.e., low and high), we can observe various groups defined according to their position in the system of factorial axes (above 0.5 values on the axes).

Five groups were defined on Dimension 1, each represented by gray-colored circles (G1.1, G1.2, G1.3, G1.4, and G1.5) while, on Dimension 2, 3 groups (G2.1, G2.2, and G2.3) were identified, each represented by red-colored circles. Further on, we will present the components of each of these groups and the associations, in terms of sustainability, for small vegetable farmers (Table 2).

The graphical representation also shows that some of the groups are situated in different quadrants. In the case of Dimension 1, the elements of groups G1.1, G1.2, and G1.3 are positioned on the right side of the graph, while the elements of groups G1.4 and G1.5 - on the left side. This means that negative associations exist between the first and the last groups. Regarding Dimension 2, the elements of groups G2.1 and G2.3 are positioned in the upper side of the graph, while those of group G2.2-in the lower side, meaning that it is negatively associated with the first two (see Figure 8 and Table 3).

In summary, associations can be observed between the diverse components of the five dimensions of sustainability, which reveals their synergy, manifested in the activities performed by small vegetable farmers from the North-East Development Region of Romania. In other words, the significant role played by certain components of the different dimensions concerning the components from other dimensions in attaining sustainability is evidenced. Consequently, if producers' goal is a sustainable activity, much attention should be paid to these types of links, which might prove decisive in obtaining high levels of sustainability. 
Table 3. Associations among sub-dimensions of sustainability.

\begin{tabular}{|c|c|c|}
\hline Group & Elements & Interpretation \\
\hline \multicolumn{3}{|c|}{ Dimension 1 (positive association_within groups) } \\
\hline $\begin{array}{c}\text { G1.1 } \\
\text { Ec_Cult }\end{array}$ & $\begin{array}{l}\text { low ec_price } \\
\text { low ec_promotion } \\
\text { low ec_tangibles } \\
\text { low cult_labor }\end{array}$ & $\begin{array}{l}\text { In conditions of poor endowment (e.g., small land area, poor machinery and } \\
\text { equipment), a low level of involvement in terms of work availability, } \\
\text { competitiveness and association/cooperation and lack of sufficient promotion } \\
\text { lead to low prices of products, unsatisfactory from farmers' point of view in } \\
\text { terms of added value. These associations confirm the importance of fixed } \\
\text { assets, cultural issues related to work and promotion of small vegetable } \\
\text { farmers for achieving satisfying economic results. }\end{array}$ \\
\hline $\begin{array}{c}\text { G1.2 } \\
\text { Env_Ec_Priv }\end{array}$ & $\begin{array}{c}\text { low env_climate_change } \\
\text { low ec_product } \\
\text { low } \\
\text { priv_factors_related_to_ } \\
\text { farm_activity }\end{array}$ & $\begin{array}{l}\text { Our findings show an association between farmers' negative perceptions on } \\
\text { climate change coupled with, on one hand, the low level of sustainability in } \\
\text { terms of (economic) product regarding the type and system of cultivation, the } \\
\text { used seeds, new technologies and agricultural practices and, on the other, the } \\
\text { unsatisfactory level of the evaluated factors which influence the activity of the } \\
\text { farm, such as the evolution of business in the last year, associated risks, steps } \\
\text { to mitigate them, most important negative or positive issues with impact upon } \\
\text { farm activity. This aspect confirms the importance of the private dimension in } \\
\text { relation to the economic product and also to sustainability, as a whole. }\end{array}$ \\
\hline
\end{tabular}

low cult_valorization_of_ personal_activity

G1.3 low soc_workforce

Cult_Soc_Ec low soc_health low ec_place high ec_price

G1.4 high ec_promotion high priv_farm_activity high env_climate_change

Ec_Priv_Env

G1.5

Env_Cult

\section{high}

env_energy_resources high cult_valorization_of_ low soc_education

Vegetable farmers who evaluate the price of products sold (according to competition, price evolution, production costs, and level of investments in the farm) can easily overestimate them in certain circumstances, such as low orientation and attention to the workforce, low contribution to the local development, low awareness and care for the health state of employees and community they are part of, and low appreciation of personal activity.

In a system where the concern for climate change reaches high levels, implying a medium- and long-term development strategy at farm level, raising support is needed to have an economically viable activity based on marketing and promotion activities, primarily to justify higher prices. This association is particularly met for the products obtained in a certified organic system. Similarly with G1.2, the associations from this group also emphasized the role of the private dimension vs. the economic and environmental ones. personal_activity
The association between high energy resources and high cultural valorization of personal activity demonstrates that vegetable farmers with an accumulated expertise over generations (family tradition) are looking for solutions to streamline the consumption of non-renewable resources.

\begin{tabular}{|c|c|c|}
\hline \multicolumn{3}{|c|}{ Dimension 2 (positive associations within groups) } \\
\hline $\begin{array}{c}\text { G2.1 } \\
\text { Ec_Cult }\end{array}$ & $\begin{array}{l}\text { low ec_incomes } \\
\text { high cult_environmental_ } \\
\text { protection }\end{array}$ & $\begin{array}{l}\text { Vegetable farmers who share the idea of environmental protection and } \\
\text { sustainable/organic agriculture do not necessarily practice an economically } \\
\text { efficient agriculture (in terms of profitability), but rather out of personal beliefs } \\
\text { about caring for nature. }\end{array}$ \\
\hline $\begin{array}{c}\text { G2.2 } \\
\text { Ec_Cult }\end{array}$ & $\begin{array}{l}\text { high ec_incomes } \\
\text { medium cult_labor }\end{array}$ & $\begin{array}{l}\text { This association highlights the fact that an average, at least, availability is } \\
\text { needed for association/cooperation, competitiveness (considering that } \\
\text { competition is beneficial), and labor power to achieve a high level of income. }\end{array}$ \\
\hline $\begin{array}{c}\text { G2.3 } \\
\text { Soc_Cult }\end{array}$ & $\begin{array}{l}\text { medium soc_workforce } \\
\text { high soc_education } \\
\text { high cult_labor }\end{array}$ & $\begin{array}{l}\text { A logical association exists among medium social workforce, high social } \\
\text { education, and high cultural labor, namely: vegetable farmers with a high level } \\
\text { of education have a medium availability compared to local employment and } \\
\text { support of local development, and a high level of cultural labor (work, } \\
\text { competitiveness, association/cooperation). Even in vegetable farmers who } \\
\text { practice conventional agriculture, there is a great value for cultural labor. }\end{array}$ \\
\hline
\end{tabular}


Table 3. Cont.

\begin{tabular}{|c|c|}
\hline Elements & Interpretation \\
\hline \multicolumn{2}{|c|}{ Dimension 1 (negative associations among groups) } \\
\hline G1.1_G1.2_G1.3 vs. G1.4_G1.5 & $\begin{array}{l}\text { The negative association between, on one hand, a high valorization of personal } \\
\text { activity and, on the other, a low favorable attitude towards association and low } \\
\text { level of promotion, can show that special focus and involvement in personal } \\
\text { activity can be both significant and able to determine extended openness to } \\
\text { association and high availability of sacrificing the free time for work. } \\
\text { A high level of farm activity in terms of future plans, satisfaction, and } \\
\text { motivation regarding it, is negatively associated with a low level of the private } \\
\text { (negative and positive, including main risks) factors regarding one's own farm } \\
\text { and its low level of promotion. This can be translated into the fact that, when } \\
\text { farm activity is conducted in a favorable context and also promoted at } \\
\text { satisfactory level, the vegetable producers are more likely to develop a good } \\
\text { perception of their activity. }\end{array}$ \\
\hline
\end{tabular}

Dimension 2 (negative associations among groups)

The tendency of a higher orientation towards association, known (at least in the Romanian context) as correlated with the idea of large-scale farming activities, is negatively linked to a high orientation towards environmental protection. Thus, the environmental concern, even the one regarding perceptions, is not necessarily associated with the idea of higher outputs and income that can be obtained through different associations for overcoming

G2.1_G2.3 vs. G2.2 difficult situations or boosting the activity.

Given that our findings show a negative association between a high level of education and a high level of income, one could leave aside the fact that generally, vegetable farmers with higher education tend to have greater expectations in terms of profitability of their farm, an aspect possibly materialized into under-valorization of this income, comparatively with the farmers with a lower level of education.

Given that, as shown in Table 3, six components of economic dimension and six components of cultural dimension, along with two social, two environmental, and two private components are present in the associations among the analyzed sub-dimensions of sustainability, at least two possible conclusions may be drawn, namely: (1) the importance of different components of the other dimensions for the economic activity of small vegetable farmers, especially in terms of product, prices, place, promotion, tangibles, and income, in the context in which the economic dimension appears to be related to all the other dimensions, through different components, such as labor, farm activity and factors related to it, valorization of personal activity, workforce, education, health, climate change, and environmental protection; (2) the necessity of not overlooking the cultural background of a small vegetable farm, that is frequently associated with the components of the economic, social, and environmental dimensions, such as price, promotion, place, tangibles, incomes, workforce, health, education, and energy resources.

\subsection{Descriptive Analysis of Different Types of Production Systems}

After analyzing the profile of the respondents and evaluating their general levels of sustainability in terms of its five dimensions (i.e., cultural, economic, environmental, private, social), it is visible that, in this regard, no difference was registered among them. In other words, each dimension of sustainability registered the same level, equal to 2, meaning that the analyzed producers are halfway on the path of attaining a sustainable activity in terms of economic, environmental, private, social, and cultural sectors (Figure 9). 

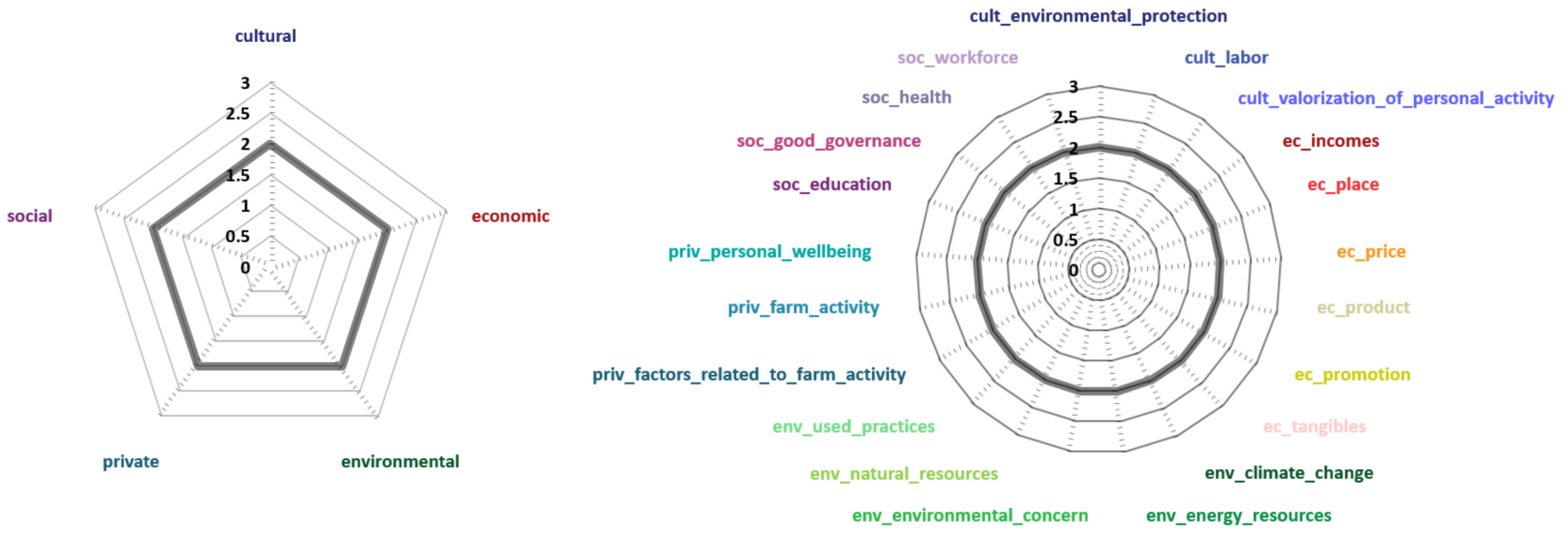

Figure 9. Sustainability dimensions and sub-dimensions for the entire sample.

To find out more about this unexpected result and to further explain it or have a clearer image upon it, the components of each dimension were also analyzed, following the same evaluation approach. Unfortunately, the same image (where all three components of cultural dimension, all six components of economic dimension, all five components of environmental dimension, all three components of private dimension, and all four components of social dimension registered the same level—equal to 2) shows that each of them, similarly to the general case, was situated approximately in the middle point between the totally unsustainable and completely sustainable path. This perspective required further analysis. Accordingly, the producers were also analyzed with reference to one of the following production systems: conventional, ecological, natural, or mixed, for highlighting the specific features of the analyzed production systems in terms of their sustainable activities.

Thus, conventional producers (Figure 10) appear to be deficient in the social sector, where the level of sustainability is decreasing, compared to the other dimensions, from 2 to 1.5. According to the analysis of its components, the deficit is seen as produced by the health and workforce characteristics. It can be also observed that the other two dimensions, (i.e., cultural and economic) register high variations of their components. Firstly, in the case of the cultural sector, it seems that the cultural values, that are related to labor, such as, mainly, work and competition, viewed as beneficial and available in terms of association, attained a maximum level of sustainability. Secondly, in the economic sector, high deficits are registered for the economic place.
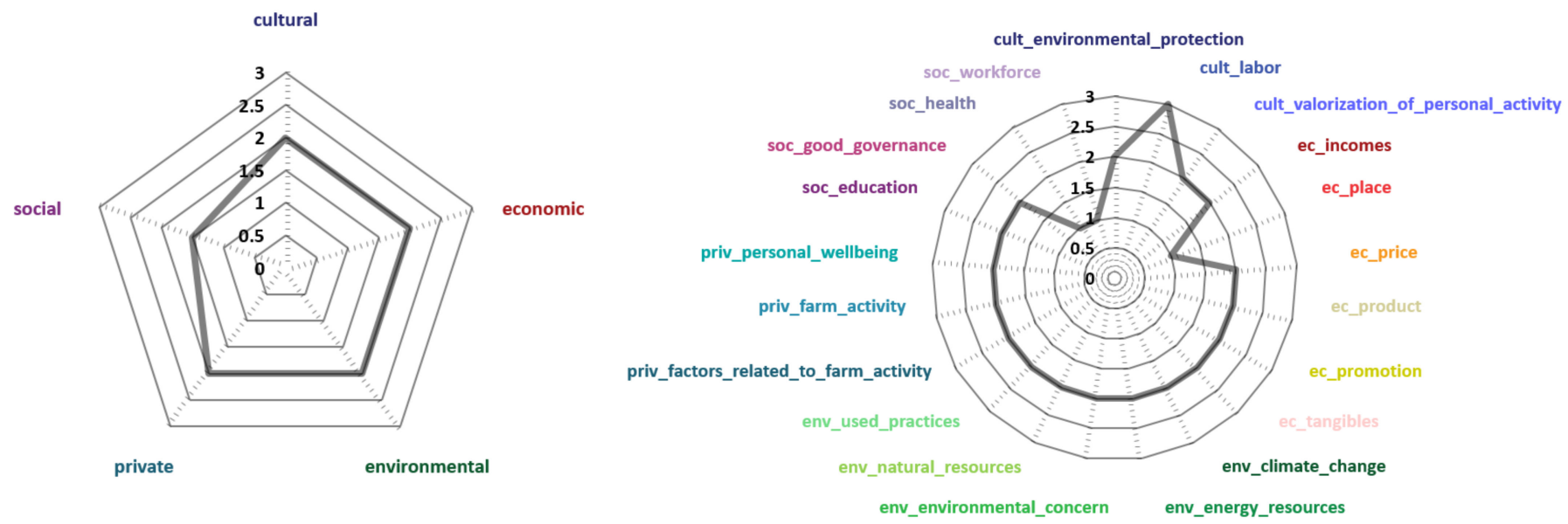

Figure 10. Sustainability dimensions and sub-dimensions for the conventional production system. 
Moving on and observing the ecological production system (Figure 11), it seems that, generally, its levels of sustainability (concerning each dimension) were the same as in the case of the conventional system (i.e., with a lower level of social sustainability, equal to 1.5, than the levels of the other dimensions, all equal to 2).
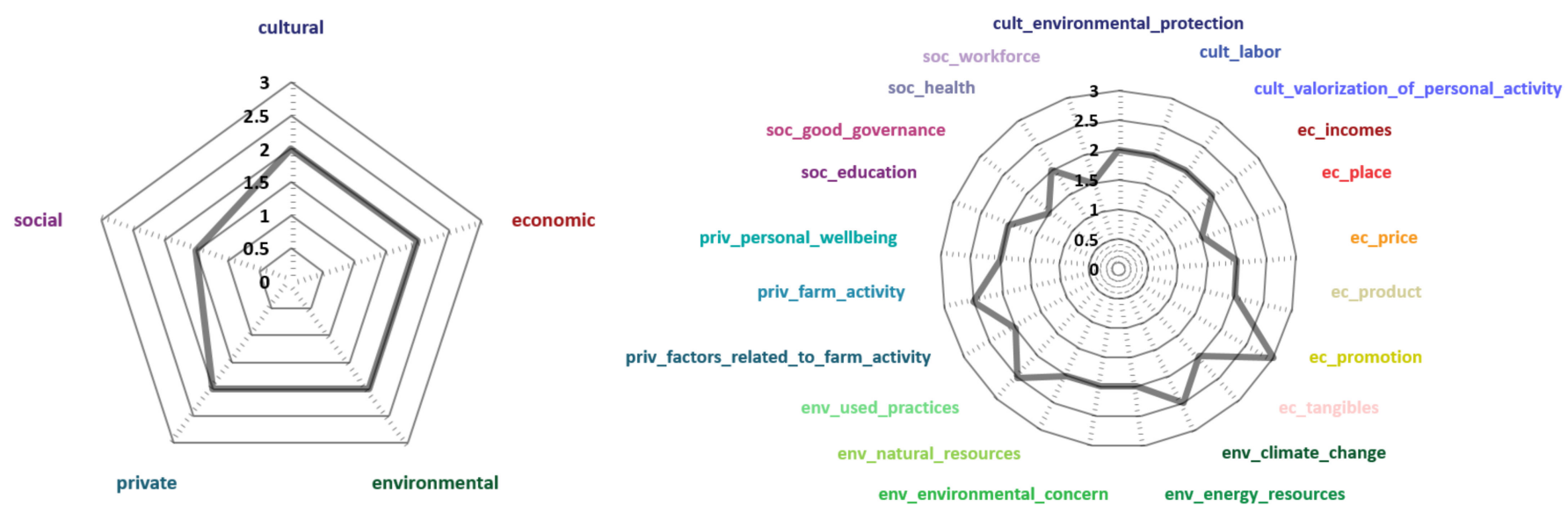

Figure 11. Sustainability dimensions and sub-dimensions for the ecologic production system.

In the more detailed analysis run on components, things change, a rather unbalanced image thus resulting. The only dimension maintaining the same level for all its components is the cultural one. The economic sector varied in its components' levels from one extreme to another: from the component related to places that registered the lowest level (equal to 1.5) to the one related to the promotion that logged the maximum level (equal to 3).

The social dimension was characterized by a low level of good governance and workforce, both equal to 1.5. The associations between workforce, education, and labor were revealed in the G2.3 (Dimension 2) group, being also supported, as observed, by this type of production system. Regarding the place of distribution, the fact that its level is lower (1.5 comparatively to 2 ) in the case of ecological producers comparatively with the conventional ones, could indicate that, in the ecological production system, a significant part of the vegetable production is distributed at local level, thus following the principle of short supply channels as contributors to the idea of sustainability.

The same general value was obtained for the natural production system (Figure 12), with a level of sustainability equal to 2 for all five dimensions, except for the social one, with a level equal to 1.5. After analyzing its components, so far, it most closely resembles the first general image (i.e., for the total respondents, regardless of the type of production system). The difference lies in the social dimension, with its education and workforce components, that register very low levels of sustainability, both equal to 1 . Thus, it appears that the associations found in the G1.4 (Dimension 1) group can be observed especially in this type of production system.

As to the mixed production system and its specific features in terms of the five dimensions of sustainability (Figure 13), the same figure as in the case of the total respondents can be observed, regardless of the type of production system. Thus, the level equal to 2 is the same whether it concerns the cultural, economic, environmental, private, or social dimension. 

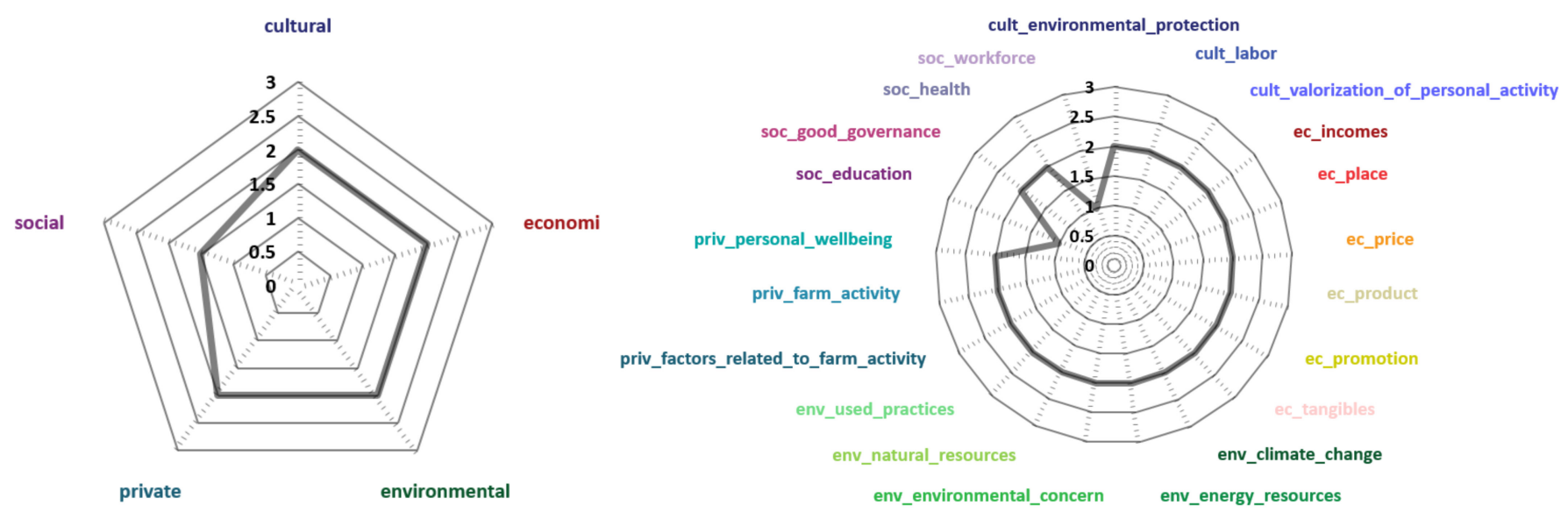

Figure 12. Sustainability dimensions and sub-dimensions for the natural production system.
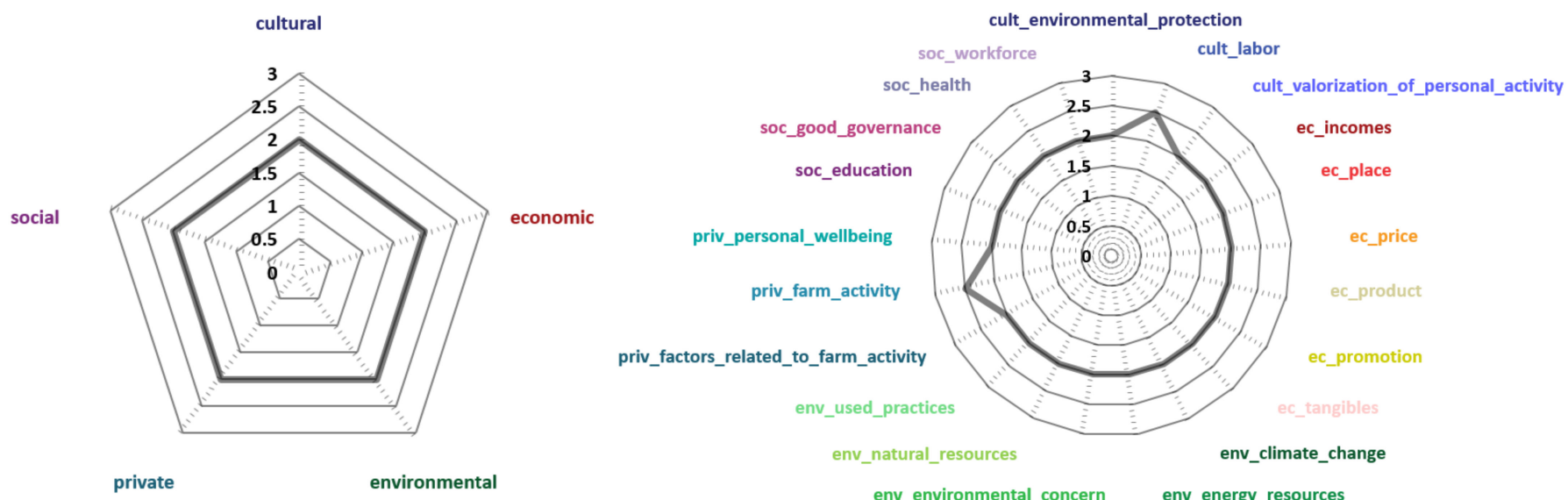

Figure 13. Sustainability dimensions and sub-dimensions for the mixed production system.

Moving on, a nearly balanced situation can be also observed when analyzing the components of each dimension. Exceptions occur for the cultural values regarding labor in the cultural dimension, and for farm activity in the private dimension, both registering values equal to 2.5, higher than those of the other components from this type of production system. These results were also highlighted by the associations found in the G1.3 (Dimension 1) group in a previous analysis, now approached at a more general level.

\section{Discussions}

Starting from the obtained results, we firstly mention that the tool we propose could respond appropriately to the adaptation desideratum in the development process, by suggesting a new way of analyzing the level of sustainability in the vegetable production system. In this way, the procedure represents a legitimate and useful endeavor, especially in the case of local producers that need to become interested in reaching and maintaining a sustainable level of their business activities.

Additionally, as a response to the need to clarify and complete the principal elements serving for development [19] (p. V), our sustainability matrix was designed for the vegetable production system. Taking into consideration the peculiarities of this type of production, frequently a family activity, our new proposed dimension, i.e., the private one, has the main role of outlining the importance of personal life in the entrepreneurial activity, especially in the agricultural one. Following Pedersen [121], who mentioned the focus on life outside work as the prerequisite for a good career, we considered that our so-called private dimension, with its components regarding personal wellbeing, satisfaction with 
actual work, future intends, personal perceptions in terms of farm activity, enriched the other four dimensions, providing a more particular aspect to our sustainability matrix. This option is also emphasized by the argument for authenticity, evidenced by Costea et al. [122] in the production process, under conditions in which being authentic unleashes creativity and ensures a proactively implication in the requirements of an organization. It is thereby argued that the personal component "is becoming a response to the question of what means a value-adding, innovative and flexible resource today" [122]. In the same way, Fleming [123] (p. 37) considered the private sphere as something productive for the working sphere.

In this respect, aspects regarding personal wellbeing (satisfaction with household's financial situation, satisfaction with personal life, degree of happiness, personal state of health, work in agriculture: hobby, farm activity: a source for achieving an adequate standard of living, spare time, and ways of spending it), specific details of the farm activity (namely, initial activity: types of crops, intent to maintain the current farm activity for five years, intent to develop the current farm activity, satisfaction with the current work, the importance of working independently) and factors related to farm (positive factors for farm activity, main risks in farm activity and ways of preventing them, importance of caring for the environment) are issues of major interest in the process of evaluating sustainability for the vegetable production system, often based on local producers. This detailed analysis, emphasizing the specific resorts of sustainability while also focusing on private elements that might offer more clarification of topical cases, can bring objectivity in our proposed measuring tool, as a necessity for all evaluation processes in general.

In the following paragraphs, the results of our study will be discussed in more detail. When analyzing all respondents in general, and also each type of production in detail, medium levels of sustainability, positioned approximately halfway to sustainability, can be noticed. Going further, in the case of a conventional production system, the weak points are related to the social dimension, especially to the health and workforce-related components, and to the economic dimension, in terms of distribution. Contrary to that, the main strength is related to the high sustainability of the work-related component included in the cultural dimension. As to the ecological aspects, the main vulnerabilities are related to the distribution from the economic dimension and to the workforce and good governance from the social sector, while the main strength seems to be the component related to promotion, included, too, in the economic dimension. The natural production system appears as unsustainable, especially in terms of workforce and education from the social dimension, yet with the same level of sustainability (not exceedingly high, equal to 2) for all the other components. According to our observations, the mixed system registered almost the same levels of sustainability, as in the case when all respondents were included in the analysis; however, higher levels were recorded for the components regarding farm activity and labor from the cultural dimension.

In more detail, firstly, the conventional production system must improve its activity, especially in terms of risks, such as exposure to pesticides, biodegradable transport packaging, and waste management plan, as well as in terms of its characteristics regarding the employees, local availability of workforce, and contribution to local development. In other words, for increasing the level of sustainability in this type of production system, it is necessary to embrace an approach based on a community-centered strategy revolving around individuals, especially the local workforce and its economic and health protection, and local development through further economic and social contribution or environmental protection. Ways of improving economic sustainability in the case of conventional production systems indicated especially the ones regarding distribution in terms of places, adaptation to market's requirements, spending, or frequency of response to customer order.

Secondly, it seems that the ecological production system focuses on promotion, creating a sustainable activity in terms of customers' loyalty and attitude, competitive advantages, and spending. For a better positioning on the market, considering the higher prices used by the entrepreneurs of this type of system, emphasis on a good promotion 
seems to be the most logical option for them, interested in strongly promoting their benefits for offering a reasonable justification for the choice of buying their products in the above-mentioned conditions. The ecological production system seems to be impeded by bureaucracy, affected by deficiency in terms of respecting the legislative framework and receiving sanctions. Additionally, it appears as unsustainable in terms of workforce characteristics, specifically employees and their local availability, and contribution to local development. Stringent aspects of sustainability, that need improvement in an ecological production system, seem related to the place of distribution, good governance, and workforce, such as adaptation of distribution to market's requirements, ways of taking orders, contribution to local development, employees, bureaucracy, rule of law, and sanctions. The sustainable path of ecological producers seemed to be linked to some important external factors that significantly contribute to their activity. In this regard, changes should come both from private initiatives and public entities, for assuring a satisfactory level of sustainability in terms of social dimension characterizing the local producers of ecological vegetables. Private initiatives could adapt to the idea of sustainable agriculture dictated by the current market context, but the need for state support, provided through sets of specific and protective measures-like subsidies or legislative, financial, material, and guidance allowances-is necessary for addressing the real necessities of producers.

Thirdly, the worst aspect of the natural production system is caused by the lack of employees with agricultural training and low level of educational contribution to local development, along with local labor shortage, which significantly affects the progress of the community.

Fourthly, in the case of the mixed production system, the higher levels of sustainability in terms of values regarding labor in the cultural dimension and farm activity in the private dimension, comparatively to the other components, can be explained by the fact that mixed agriculture is practiced especially by experienced farmers in this domain, capable to better adapt themselves to the market requirements, and open to the solution of association, known as better securing the long-term development of their businesses.

Considering the results recorded in the mixed system, that registered the higher levels of sustainability, additional explanations could be pointed out, based on the regional context of Romania. The specificity of the vegetable production from the North-East Development Region of Romania, characterized especially by small farms mainly practiced in the field, using human workforce within the family and with a low level of technical endowments (agricultural machines and technical equipment) [117,124], low storage capacity and processing made mainly in the household, with a market based on the principles of short distribution chains, attaining of durable economic results imposes to the small vegetable farmers their orientation towards a preponderantly mixed production system. Adding to this the climate changes manifested in the last period, this solution is the main viable one for assuring the stability of production, offering diversity, inclusively qualitative diversity. In the same way, this category of farmers becomes more prepared to satisfy the needs and requirements of a larger part of consumers (with low or high income, promoters of local healthy natural products), offering to them resilience.

Mention should be also made of the fact that the Romanian consumer does not prefer an ecologically certified product and is not willing to pay a higher price when the only difference is the legal certification. Consequently, the vegetable farmers from Romania should attentively consider consumer needs and their level of acceptability regarding the ecologically certified products, comparatively to the natural ones $[125,126]$.

The conclusions of this part of the study show the differences in terms of levels of dimensions and sub-dimensions of sustainability according to the type of production system under analysis. Based on these findings, the division we established in terms of types of production system proved to be useful for a deeper understanding of the main vulnerabilities and necessary solutions, somewhat clearing the path towards a sustainable activity of the vegetable producers from the North-East Development Region of Romania. 
Our results should, however, take into consideration certain limits. In this respect, we start by pointing out the general limit of all endeavors that imply creating tools for measuring sustainability, i.e., the impossibility of conceptualizing a complete methodology that includes all aspects related to the dimensions of sustainability, for offering a complete image of what really sustainability means in a certain context. Another limit is that this tool is not fully quantitative, relying as well on a qualitative assessment based on farmer's point of view. Additionally, a daunting problem in the study comes from the impossibility of applying the analysis to a larger number of respondents or of providing a balance among the producers involved in a specific type of production system (conventional, ecologic, natural, mixed). Thus, considering that the focus of our analysis was on the North-East Development Region of Romania, future research may also employ a large-scale analysis that will include other regions of this country or of other countries. Further, based on our results, especially those identifying the main vulnerabilities of the vegetable producers, future research could include an extensive and punctual analysis for each of them, for increasing the degree of understanding and for pioneering methods for overcoming the weak aspects.

\section{Conclusions}

Sustainability represents a relative concept whose meaning varies with the evolution of society as a whole. Nevertheless, there is always room for improvement, especially when an intent of evaluating sustainability occurs. In this context, the continuing need for updating the concept based on changes registered across the entire society and in specific areas of analysis could appear as both explicit and challenging.

Consequently, we proposed a new approach for measuring sustainability in the case of vegetable production systems, which could represent a legitimate and useful endeavor for the farmers interested in securing a sustainable path for the development of their business. In this way, we aimed at attaining a distinct image of what sustainability could mean in this case, dividing its specific features into three main dimensions (economic, social, and environmental), while adding the cultural and private ones. More punctually, the main goal of this study was to run a diagnostic on sustainability of the vegetable production systems, with focus on the North-East Development Region of Romania. While leaning on the founding principles of sustainability for determining what it represents in the current context of the analyzed vegetable producers, the added value of our investigation could emerge from integrating the private dimension within the proposed sustainability matrix. This approach can, in our opinion, refine the general capacity of producers to successfully meet the sustainability goals in their entrepreneurial activity.

Based on these general assumptions, the main results of the analysis run on the small vegetable farmers from the North-East Region of Romania refer firstly to the findings related to the associations observed among the various components of the five dimensions of sustainability. Furthermore, these associations reveal their synergy in farm activity and the significant role played in the process of attaining sustainability, by some components from different dimensions in relation to the components from other dimensions. Consequently, if producers aim at having a sustainable activity, attention should be also paid to these types of links that, in such a context, could prove decisive. In addition, we pointed out the importance of different components of the other dimensions for the economic activity of the small vegetable farmers, especially in terms of product, prices, place, promotion, tangibles, and income, whereas the economic dimension appears to be linked to all the other four dimensions. Our findings have also highlighted the necessity of not overlooking the cultural background of a small vegetable farm activity, which is frequently associated with the components of the economic, social, and environmental dimensions, such as price, promotion, place, tangibles, incomes, workforce, health, education, and energy resources.

Secondly, we embraced both a general and individual approach (by analyzing all types of production systems and investigating them separately, respectively) that revealed medium levels of sustainability, placing the vegetable farms nearly halfway to their path- 
ways to achieving sustainability. Moreover, depending on the type of production system, different weak points were identified, as follows: (1) weaknesses associated with the social dimension, especially with the health and workforce-related components, and with the economic dimension in terms of distribution, in the case of the conventional production system; (2) vulnerabilities in terms of distribution, from the economic dimension, and vulnerabilities of the workforce and good governance, from the social sector, in the ecological case; (3) weaknesses in terms of workforce and education from the social dimension, yet registering low levels of sustainability for all the other components, when the natural production system was analyzed; (4) the mixed system was observed to register almost the same levels of sustainability as that recorded when the analysis included all respondents, but with high levels for the components regarding farm activity and labor from the cultural dimension.

Based on these findings, our endeavor proved useful for understanding the main vulnerabilities in terms of sustainability and managing the possible solutions for taking the correct path towards a sustainable activity in the vegetable production from the North-East Development Region of Romania. Moreover, the sustainability matrix suggested here can be a tool with applications in other different local, regional, national contexts, with the same aim of evaluating the level of sustainability in the case of small vegetable farmers.

Author Contributions: Conceptualization, I.S.B., S.-R.U., C.C., and L.T.; methodology, I.S.B., C.C., S.-R.U., and L.T.; software, C.C.; validation, I.S.B., S.-R.U., and L.T.; formal analysis, S.-R.U., C.C., and L.T.; investigation, I.S.B., S.-R.U., C.C., and L.T.; data curation, I.S.B. and G.V.H.; writing-original draft preparation, I.S.B., S.-R.U., C.C., and L.T.; writing-review and editing, I.S.B., S.-R.U., C.C., and L.T.; visualization, S.-R.U. and C.C.; project administration, I.S.B.; funding acquisition, I.S.B. All authors have read and agreed to the published version of the manuscript.

Funding: This research was funded by GoEAThical project (European youth stand up for sustainable food supply chains that respect migrant workers' rights and reduce climate change, hunger, and poverty as key drivers of migration), CSO-LA/2020/411-443, financed by the European Union through DEAR programme.

Institutional Review Board Statement: Not applicable.

Informed Consent Statement: Not applicable.

Acknowledgments: The authors would like to thank their colleagues: Codrin Dinu Vasiliu, Anca Chirilă Gheorghică, and Sebastian Dobos for their support in elaborating the questionnaire for data collection. This material is supported by the Mai bine Association of Iași through the project GoEAThical, funded by the European Union. \#GoEAThical is a global consortium of 16 organizations from Europe, South Africa, and South America (Brazil), coordinated by the Christliche Initiative Romero Association in Germany. The manuscript, written by team members of the Rural Development Research Platform Association, does not necessarily reflect the official position of the European Union. Thanks also go to Sonia Bulei, for contributing to the English review of the manuscript. We would like to thank our reviewers for the suggestions which permitted to improve this material.

Conflicts of Interest: The authors declare no conflict of interest.

\section{Appendix A}

Table A1. Detail description of the questionnaire applied to small vegetable farmers.

\begin{tabular}{ll}
\hline $\begin{array}{c}\text { Section } \\
\text { Sub-Dimension }\end{array}$ & Questions \\
\hline Economic & \\
\hline Incomes & $\begin{array}{l}\text { 1. Do you have any other sources of income besides your farm income? } \\
\text { 2. Is this your primary source of income for your family? } \\
\text { 3. How profitable do you believe your business is? }\end{array}$ \\
\hline
\end{tabular}


Table A1. Cont.

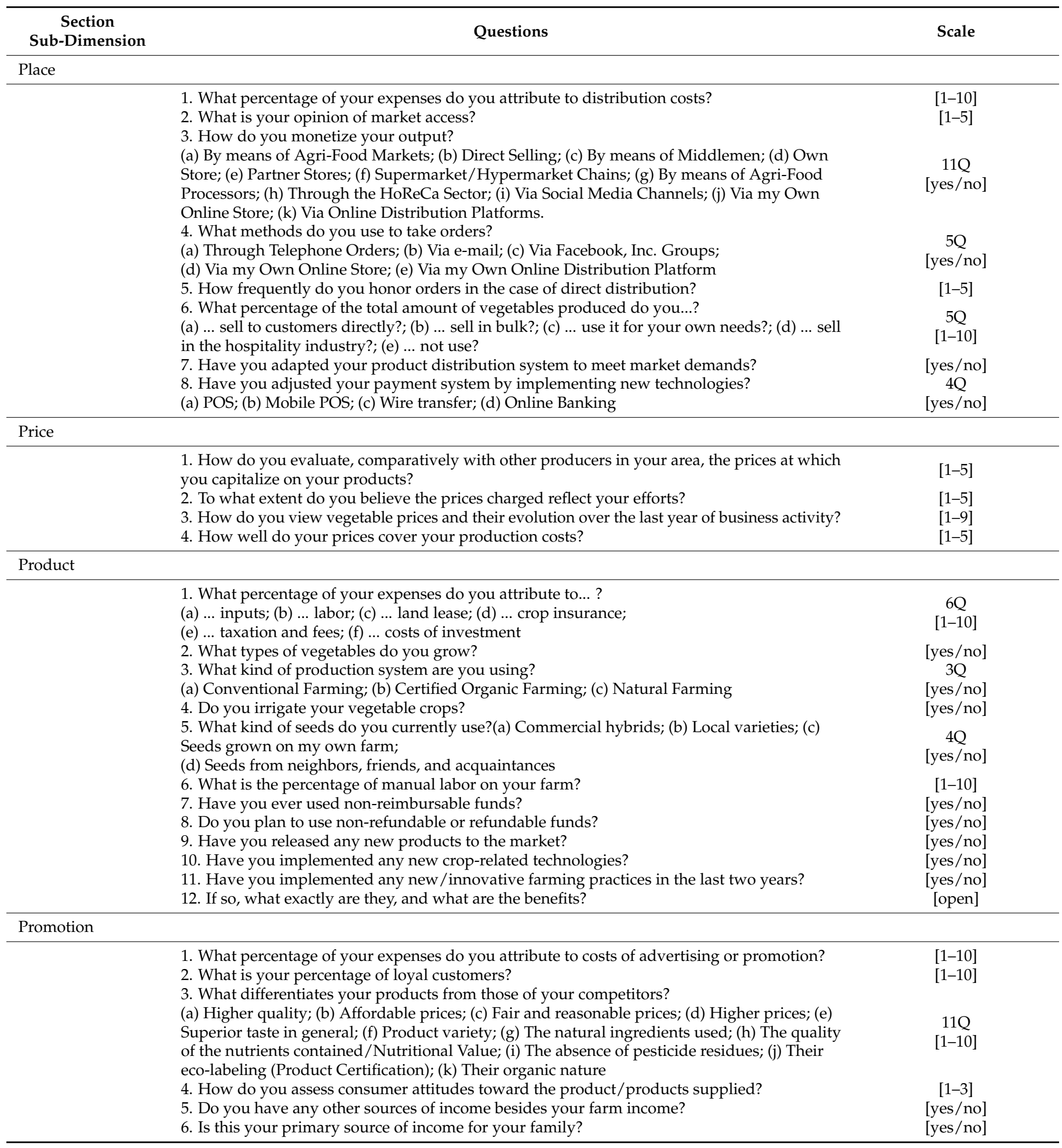


Table A1. Cont.

\begin{tabular}{|c|c|c|}
\hline $\begin{array}{c}\text { Section } \\
\text { Sub-Dimension }\end{array}$ & Questions & Scale \\
\hline \multicolumn{3}{|l|}{ Tangibles } \\
\hline & $\begin{array}{l}\text { 1. How large is the total area which you are currently farming? } \\
\text { 2. What percentage of the total area do you own? } \\
\text { 3. What is the total area which you have taken out on lease? } \\
\text { 4. What is the size of the vegetable-growing area? } \\
\text { 5. Do you have animals on your farm? } \\
\text { 6. Do you currently own any farm machinery or equipment? } \\
\text { 7. In 2020, compared to 2019, how is the evolution of the total area dedicated to vegetable } \\
\text { crops? } \\
\text { 8. Did you make any investments in the farm in } 2020 \text { ? } \\
\text { 9. If so, please identify the type of investment. } \\
\text { (a) Capital Goods; (b) Means of Distribution; (c) Costs of adopting new technology; (d) } \\
\text { Creation and launch of an online store; (e) Investment in on-line advertising; (f) Courses and } \\
\text { Specializations; (g) Infrastructure Developments-IT\&C }\end{array}$ & $\begin{array}{c}\text { [open] } \\
\text { [open] } \\
\text { [open] } \\
\text { [open] } \\
\text { [yes } / \text { no] } \\
\text { [yes } / \text { no] } \\
{[1-3]} \\
{[y e s / n o]} \\
7 Q \\
\text { [yes } / \text { no] }\end{array}$ \\
\hline \multicolumn{3}{|l|}{ Social } \\
\hline \multicolumn{3}{|l|}{ Education } \\
\hline & $\begin{array}{l}\text { 1. Do you pay workers with agricultural degrees on your farm? } \\
\text { 2. To what extent do you believe your business contributes to local development by providing } \\
\text { support to the local education system? }\end{array}$ & $\begin{array}{c}\text { [yes/no] } \\
{[1-10]}\end{array}$ \\
\hline \multicolumn{3}{|l|}{ Good governance } \\
\hline & $\begin{array}{l}\text { 1. How would you rate the impact of bureaucracy on your activity? } \\
\text { 2. How do you deem the following: } \\
\text { (a) Do most local producers in the area comply with the specific legislative framework?; (b) Do } \\
\text { vegetable growers usually face penalties for failing to comply with the specific legislative } \\
\text { framework?; (c) Do local vegetable growers in the area face penalties for failing to comply with } \\
\text { the specific legislative framework? }\end{array}$ & $\begin{array}{c}{[1-10]} \\
3 Q \\
{[1-5]}\end{array}$ \\
\hline \multicolumn{3}{|l|}{ Health } \\
\hline & $\begin{array}{l}\text { 1. Do you think your farm workers are exposed to pesticides? } \\
\text { 2. Is the packaging you're using biodegradable? } \\
\text { 3. Do you currently have a manure storage facility? } \\
\text { 4. Do you normally generate an excessive amount of manure? } \\
\text { 5. Do you have a waste management strategy in place to reduce the amount of waste } \\
\text { generated? } \\
\text { 6. If not, do you plan to do something about it in the future? }\end{array}$ & $\begin{array}{l}{[1-10]} \\
{[\text { yes } / \text { no] }} \\
{[\text { yes } / \text { no] }} \\
{[\text { yes } / \text { no] }} \\
{[\text { yes } / \text { no] }} \\
{[y e s / n o]}\end{array}$ \\
\hline \multicolumn{3}{|l|}{ Workforce } \\
\hline & $\begin{array}{l}\text { 1. How many individuals are currently working on the farm? } \\
\text { 2. How many members of your family are currently working on the farm? } \\
\text { 3. The labor force engaged in the following activities in 2020, compared to } 2019 \text { was the } \\
\text { same/increased/decreased in terms of... } \\
\text { (a) ... production; (b) ... processing and packaging; (c) ... distribution and sales } \\
\text { 4. To what extent do you believe your business contributes to local development by providing } \\
\text { gainful employment? } \\
\text { 5. To what extent do you believe your business contributes to local development by providing } \\
\text { gainful employment? } \\
\text { 6. To what extent do you believe your business contributes to local development by boosting } \\
\text { local entrepreneurship? } \\
\text { 7. How would you rate labor availability/accessibility in your area? }\end{array}$ & $\begin{array}{c}\text { [open] } \\
\text { [open] } \\
3 \mathrm{Q} \\
{[1-3]} \\
{[1-10]} \\
{[1-10]} \\
{[1-10]} \\
{[1-10]}\end{array}$ \\
\hline \multicolumn{3}{|l|}{ Environmental } \\
\hline \multicolumn{3}{|l|}{ Climate change } \\
\hline & $\begin{array}{l}\text { 1. Do you believe that climate change poses a threat to your business? } \\
\text { 2. To what extent do you believe the following climatic events have an impact on your activity? } \\
\text { (a) Floods; (b) Thunderstorms; (c) Meteorological drought; } \\
\text { (d) Hydrological drought; (e) Heavy rain; (f) Heat waves; (g) Cold snaps; } \\
\text { (h) Hailstorms; (i) Late frosts; (j) Decreased snow cover } \\
\text { 3. To what extent do you believe climate change can affect? } \\
\text { (a) Crop yields; (b) Trees and shrubs; (c) Gardens; (d) Overall health and well-being; (e) } \\
\text { Revenue and cash flows; (f) Domestic livestock; (g) Biodiversity on a local scale; (h) Crop } \\
\text { rotation; (i) Household }\end{array}$ & $\begin{array}{c}\text { [yes } / \text { no] } \\
10 \mathrm{Q} \\
{[1-10]}\end{array}$ \\
\hline
\end{tabular}


Table A1. Cont.

\begin{tabular}{|c|c|c|}
\hline $\begin{array}{c}\text { Section } \\
\text { Sub-Dimension }\end{array}$ & Questions & Scale \\
\hline \multicolumn{3}{|l|}{ Energy resources } \\
\hline & $\begin{array}{l}\text { 1. These settlements are approximately how far away from you, in kilometers? } \\
\text { 2. How do you transport the finished product/goods to be sold on the market? }\end{array}$ & [open] \\
\hline & $\begin{array}{l}\text { 2. How do you transport the finished product/goods to be sold on the market? } \\
\text { (a) Using my Own Diesel-Powered Road Vehicle; (b) Using my Own Gas-Powered Road }\end{array}$ & $4 \mathrm{Q}$ \\
\hline & $\begin{array}{l}\text { Vehicle; (c) I use Vehicle-Rental Services/Commercial Transport Services; (d) I make use of } \\
\text { Distribution Services }\end{array}$ & [yes/no] \\
\hline & 3. How do you evaluate your own overall energy consumption in business-related activities? & {$[1-3]$} \\
\hline & 4. What is the percentage of diesel consumption in total fossil fuel consumption? & [1-10] \\
\hline & $\begin{array}{l}\text { 5. Do you also use farm-produced electricity as a source of energy (wind turbines, solar } \\
\text { panels)? }\end{array}$ & [yes/no] \\
\hline & 6. What percentage of total energy consumption would be accounted for by alternative energy? & [1-10] \\
\hline & $\begin{array}{l}\text { 7. Do you plan to use alternative sources of electricity generated on the farm in the future } \\
\text { (solar panels, wind turbines)? }\end{array}$ & [yes/no] \\
\hline \multicolumn{3}{|c|}{ Environmental concern: actions } \\
\hline & 1. Do you reuse transportation packaging (bags, crates, and sacks)? & [yes/no] \\
\hline & 2. Do you recycle transport packaging (bags, crates, and sacks)? & [yes/no] \\
\hline & 3. Do you employ composting methods for your used biodegradable packaging? & [yes/no] \\
\hline & 4. What measures are you taking right now to reduce your environmental impact? & [open] \\
\hline \multicolumn{3}{|l|}{ Natural resources } \\
\hline & 1. In which class is the soil you are currently farming? & [1-5] \\
\hline & $\begin{array}{l}\text { 2. What kind of fertilizer do you apply? } \\
\text { (a) Manure; (b) Compost; (c) Soil-applied chemical fertilizers; (d) Foliar chemical fertilizers; (e) } \\
\text { Ecological fertilizers }\end{array}$ & $\begin{array}{c}5 \mathrm{Q} \\
\text { [yes/no] }\end{array}$ \\
\hline & $\begin{array}{l}\text { 3. Out of the total fertilizer quantity used, how much... } \\
\text { (a) ... is manure?; (b) ... is compost?; (c) ... is ecologically certified?; (d) ... are soil-applied } \\
\text { chemical fertilizers?; (e) ... are foliar chemical fertilizers? }\end{array}$ & $\begin{array}{c}5 \mathrm{Q} \\
\text { [yes/no] }\end{array}$ \\
\hline & 4. Can you tell us where the water used for irrigation comes from? & $5 \mathrm{Q}$ \\
\hline & $\begin{array}{l}\text { (a) Groundwater; (b) Watercourse (spring, stream, river); (c) Public water supply system; (d) } \\
\text { Lake or pond; (e) Rainwater collection system }\end{array}$ & [yes/no] \\
\hline & 5. Do you currently have rainwater collection systems? & [yes/no] \\
\hline & 6. Do you currently have water-monitoring systems in place? & [yes/no] \\
\hline & 7. How do you personally believe the amount of water consumed per production is? & {$[1-3]$} \\
\hline \multicolumn{3}{|l|}{ Used practices } \\
\hline & 1. The following methods are used in the fight against diseases: & $3 Q$ \\
\hline & (a) Chemical; (b) Natural; (c) Ecological & [yes/no] \\
\hline & 2. Methods for weed control include: & $5 \mathrm{Q}$ \\
\hline & (a) Chemical; (b) Mechanical; (c) Thermal; (d) Specific to organic farming; (e) Manual & [yes/no] \\
\hline & 3. Pest control is accomplished using the following methods: & $4 Q$ \\
\hline & (a) Chemical; (b) Natural; (c) Manual; (d) Ecological & [yes/no] \\
\hline & 4. Do you need to use plastics in your work-related/business activities? & {$[1-5]$} \\
\hline & 5. Do you make use of mulch film? & [yes/no] \\
\hline & 6. Is the mulch film you're using reusable? & [yes/no] \\
\hline & 7. What do you do with used plastic materials? & [open] \\
\hline & 8. What do you do with the packaging of the chemicals that you use? & [open] \\
\hline & 9. Do you recover/reclaim transportation packaging (bags, crates, and sacks)? & [yes/no] \\
\hline & 10. Do you generate any organic waste on your farm? & [yes/no] \\
\hline & 11. Do you generate any inorganic waste on your farm? & [yes/no] \\
\hline & 12. What percentage of crop residues do you compost? & {$[1-10]$} \\
\hline \multicolumn{3}{|l|}{ Cultural } \\
\hline \multicolumn{3}{|c|}{ Cultural values: labor } \\
\hline & $\begin{array}{l}\text { 1. Did you associate with other people in order to overcome difficult moments/difficult } \\
\text { situations and boost your activity? }\end{array}$ & [yes/no] \\
\hline & 2. Should work always take precedence over leisure, even if it means less spare time? & [1-10] \\
\hline & 3. Is competition, in your opinion, beneficial or detrimental? & {$[1-10]$} \\
\hline \multicolumn{3}{|c|}{ Environmental concern: perceptions } \\
\hline & 1. Do you believe that people should be more open in terms of environmental protection? & [1-5] \\
\hline & $\begin{array}{l}\text { 2. To what extent do you believe that environmental protection should be prioritized, even if it } \\
\text { means slower growth and job losses? }\end{array}$ & {$[1-10]$} \\
\hline & $\begin{array}{l}\text { 3. To what extent do you believe it is true that economic development and job creation should } \\
\text { take precedence, even if the environment suffers as a result? }\end{array}$ & [1-10] \\
\hline & 4. Is, for you, the issue of environmental degradation quite real? & {$[1-10]$} \\
\hline
\end{tabular}


Table A1. Cont.

\begin{tabular}{|c|c|c|}
\hline $\begin{array}{c}\text { Section } \\
\text { Sub-Dimension }\end{array}$ & Questions & Scale \\
\hline \multicolumn{3}{|c|}{ Valorization of personal activity } \\
\hline & 1. Is growing vegetables a tradition in your family? & [yes/no] \\
\hline & 2. Is vegetable farming an important economic activity in your area? & [yes/no] \\
\hline & $\begin{array}{l}\text { 3. To what extent do you believe your business contributes to local development by providing } \\
\text { support to the preservation of the local heritage and customs? }\end{array}$ & {$[1-10]$} \\
\hline & $\begin{array}{l}\text { 4. To what extent do you believe your business contributes to local development by providing } \\
\text { an appropriate model of good practices? }\end{array}$ & [1-10] \\
\hline \multicolumn{3}{|l|}{ Private } \\
\hline \multicolumn{3}{|c|}{ Factors related to farm activity } \\
\hline & $\begin{array}{l}\text { 1. How would you rate the evolution of your business in the last year? } \\
\text { 2. Please rate the following negative factors' impact on activity in 2020: }\end{array}$ & [1-10] \\
\hline & $\begin{array}{l}\text { (a) Drought; (b) Hailstorms; (c) Agricultural pests; (d) Plant diseases; (e) Cold snaps/Cold } \\
\text { waves/Frost; (f) Strong winds; (g) Flood damage; (h) The COVID-19 pandemic and its } \\
\text { associated effects; (i) Labor shortage; (j) Poor market access; } \\
\text { (k) The decline in demand in the HoReCA Sector }\end{array}$ & $\begin{array}{c}11 Q \\
{[1-10]}\end{array}$ \\
\hline & 3. Is your business seasonal? & [yes/no] \\
\hline & 4. Do you place a high value on protecting the environment? & {$[1-5]$} \\
\hline & $\begin{array}{l}\text { 5. What were the most important positive factors that influenced the growth of the business in } \\
2020 \text { ? }\end{array}$ & [open] \\
\hline & 6. What are the risks associated with your business? & [open] \\
\hline & 7. What steps do you take to mitigate these risks? & [open] \\
\hline \multicolumn{3}{|l|}{ Farm activity } \\
\hline & 1. Do you plan on staying in business in the next five years? & [yes/no] \\
\hline & $\begin{array}{l}\text { 2. If this is the case, you intend to expand the activity by doing the following: } \\
\text { (a) Farmland expansion; (b) Technology investments / Agricultural technology adoption; (c) }\end{array}$ & \\
\hline & $\begin{array}{l}\text { Investments in digital farming/Digital transformation; } \\
\text { (d) Expanding the workforce; (e) Growth of product lines/Categories; } \\
\text { (f) Investments in the processing area; (g) Transition to organic crop production; } \\
\text { (h) Diversify my marketing channels }\end{array}$ & $\begin{array}{c}8 \mathrm{Q} \\
{[\mathrm{yes} / \mathrm{no}]}\end{array}$ \\
\hline & 3. How pleased are you with your current job and business? & {$[1-10]$} \\
\hline & 4. How important is it for you to be able to work on your own/independently? & {$[1-10]$} \\
\hline & 5. Reasons why you run your own business: & \\
\hline & (a) Taking advantage of a business opportunity; (b) Better income prospects; & $5 \mathrm{Q}$ \\
\hline & $\begin{array}{l}\text { (c) The freedom to choose where and when to work; (d) There are not any appealing job } \\
\text { opportunities for me/my family and/or my friends. I am self-employed; (e) To avoid/prevent } \\
\text { uncertainty in paid employment }\end{array}$ & {$[1-10]$} \\
\hline & 6. Do you believe that working on the farm takes up a considerable amount of your time? & $1-3$ \\
\hline \multicolumn{3}{|l|}{ Personal well being } \\
\hline & 1. How content are you with your household's financial situation? & [1-10] \\
\hline & 2. How would you describe your current state of health? & {$[1-4]$} \\
\hline & 3. How satisfied are you with your life generally, considering all elements? & {$[1-10]$} \\
\hline & 4. Please rate your level of happiness/fulfillment. & {$[1-10]$} \\
\hline & 5. Do you consider your involvement in the agricultural sector to be a passion? & [yes/no] \\
\hline & 6. Do you believe that the activity you engage in ensures a decent standard of living? & [yes/no] \\
\hline & 7. What do you like to do in your spare time? & [open] \\
\hline & 8. Do you usually take vacations? & {$[1-5]$} \\
\hline & 9. Would you be prepared to give up your job? & [yes/no] \\
\hline \multicolumn{3}{|l|}{ Socio-demographic } \\
\hline & 1. Gender & {$[1,2]$} \\
\hline & 2. Age & {$[1-6]$} \\
\hline & 3. Educational attainment & [1-6] \\
\hline
\end{tabular}

Table A2. Detail recoding procedure for each scale from the questionnaire.

\begin{tabular}{ccccccccc}
\hline \multirow{2}{*}{ Level } & \multicolumn{10}{c}{ Scale } \\
\cline { 2 - 9 } & [Yes/No] & {$[\mathbf{1 - 3}]$} & {$[\mathbf{1 - 4}]$} & {$[\mathbf{1 - 5}]$} & {$[\mathbf{1 - 6}]$} & {$[\mathbf{1 - 9}]$} & {$[\mathbf{1 - 1 0 ]}$} & [Open] \\
\hline Low & no & 1 & 1 & 1,2 & 1,2 & $1,2,3$ & $1,2,3$ & coded and allocated to a level \\
Medium & no representation & 2 & 2,3 & 3 & 3,4 & $4,5,6$ & $4,5,6,7$ & more appropriate to the context \\
High & yes & 3 & 4 & 4,5 & 5.6 & $7,8,9$ & $8,9,10$ & \\
\hline
\end{tabular}




\section{References}

1. Talukder, B.; Blay-Palmer, A.; Vanloon, G.W.; Hipel, K.W. Towards complexity of agricultural sustainability assessment: Main issues and concerns. Environ. Sustain. Indic. 2020, 6, 100038. [CrossRef]

2. Bell, S.; Morse, S. Sustainability Indicators: Measuring the Immeasurable? Routledge: London, UK, 2008.

3. DFID. Sustainable Agriculture. Key Sheet. 2003. Available online: http://www.odi.org.uk/sites/odi.org.uk/files/odi-assets/ publications-opinion-files/3143.pdf (accessed on 5 January 2019).

4. UN. Transforming Our World: The 2030 Agenda for Sustainable Development. Available online: https://sdgs.un.org/2030agenda (accessed on 10 February 2021).

5. Lehtinen, U. Sustainability and local food procurement: A case study of Finnish public catering. Br. Food J. 2012, $114,1053-1071$. [CrossRef]

6. Avetisyan, M.; Hertel, T.; Sampson, G. Is Local Food More Environmentally Friendly? The GHG Emissions Impacts of Consuming Imported versus Domestically Produced Food. Environ. Resour. Econ. 2013, 58, 415-462. [CrossRef]

7. Meas, T.; Hu, W.; Batte, M.T.; Woods, T.A.; Ernst, S. Substitutes or Complements? Consumer Preference for Local and Organic Food Attributes. Am. J. Agric. Econ. 2015, 97, 1044-1071. [CrossRef]

8. Schwarz, J.; Schuster, M.; Annaert, B.; Maertens, M.; Mathijs, E. Sustainability of Global and Local Food Value Chains: An Empirical Comparison of Peruvian and Belgian Asparagus. Sustainability 2016, 8, 344. [CrossRef]

9. Blay-Palmer, A. Food Fears: From Industrial to Sustainable Food Systems; Ashgate Publishing: Aldershot, UK, 2008.

10. Kushi, L.H.; Nestle, M. Food Politics: How the Food Industry Influences Nutrition and Health; University of California Press: Berkeley, CA, USA, 2013.

11. Murdoch, J.; Marsden, T.; Banks, J. Quality, Nature, and Embeddedness: Some Theoretical Considerations in the Context of the Food Sector. Econ. Geogr. 2009, 76, 107-125. [CrossRef]

12. DuPuis, E.M.; Goodman, D. Should we go "home" to eat?: Toward a reflexive politics of localism. J. Rural. Stud. 2005, 21, 359-371. [CrossRef]

13. Morgan, K. Local and Green, Global and Fair: The Ethical Foodscape and the Politics of Care. Environ. Plan. A Econ. Space 2010, 42, 1852-1867. [CrossRef]

14. Brunori, G.; Galli, F.; Barjolle, D.; Van Broekhuizen, R.; Colombo, L.; Giampietro, M.; Kirwan, J.; Lang, T.; Mathijs, E.; Maye, D.; et al. Are Local Food Chains More Sustainable than Global Food Chains? Considerations for Assessment. Sustainability 2016, 8 , 449. [CrossRef]

15. Organisation for Economic Co-Operation and Development. Guidance on Sustainability Impact Assessment; Organisation for Economic Co-Operation and Development (OECD): Paris, France, 2010.

16. Laedre, O.; Haavaldsen, T.; Bohne, R.A.; Kallaos, J.; Lohne, J. Determining sustainability impact assessment indicators. Impact Assess. Proj. Apprais. 2014, 33, 98-107. [CrossRef]

17. Mihai, C.; Hatmanu, M. Particular Aspects of Consumer Profile of the Public Goods Generated in a Region with Extensive Agricultural Activities: The Case of Dorna Valley Area of Romania. Eurint 2018, 5, 272-288.

18. Parris, T.M.; Kates, R.W. Characterizing and Measuring Sustainable Development. Annu. Rev. Environ. Resour. 2003, 28, 559-586. [CrossRef]

19. Pohoaţă, I.; Diaconaşu, D.E.; Crupenschi, V.M. The Sustainable Development Theory: A Critical Approach. In The Sustainable Development Theory: A Critical Approach; Palgrave Macmillan: London, UK, 2020; Volume 1, pp. 1-31.

20. Connelly, S. Mapping Sustainable Development as a Contested Concept. Local Environ. 2007, 12, 259-278. [CrossRef]

21. Pesqueux, Y. Sustainable development: A vague and ambiguous "theory". Soc. Bus. Rev. 2009, 4, 231-245. [CrossRef]

22. Hopwood, B.; Mellor, M.; O’Brien, G. Sustainable development: Mapping different approaches. Sustain. Dev. 2005, 13, 38-52. [CrossRef]

23. Moldan, B.; Billharz, S. Sustainability Indicators: A Report on the Project on Indicators of Sustainable Development; Wiley: New York, NY, USA, 1997.

24. Meadows, D. Indicators and Information Systems for Sustainable Development; The Sustainability Institute: Hartland, VT, USA, 1998. Available online: https:/ / donellameadows.org/wp-content/userfiles/IndicatorsInformation.pdf (accessed on 10 April 2021).

25. Bosse, H. Indicators for Sustainable Development: Theory, Method, Applications. A Report to the Balaton Group; International Institute for Sustainable Development: Winnipeg, MB, Canada, 1999.

26. Commission on Sustainable Development. Indicators of Sustainable Development: Framework and Methodologies. J. Clean. Prod. 2001, 9, 294.

27. Van de Kerk, G.; Manuel, A. Sustainable Society Index-Your Compass to Sustainability; Sustainable Society Foundation: The Netherlands, 2017.

28. Esty, D.; Levy, M.; Srebotnjak, T.; De Sherbinin, A.; Kim, C.; Anderson, B. Pilot 2006 Environmental Performance Index; Yale Center for Environmental Law \& Policy: New Haven, CT, USA, 2006.

29. Ewing, B.; Moore, D.; Goldfinger, S.H.; Oursler, A.; Reed, A.; Wackernagel, M. Ecological Footprint Atlas 2010; Global Footprint Network: Oakland, CA, USA, 2010; pp. 1-111.

30. UNDP. Human Development Report 2014—Sustaining Human Progress: Reducing Vulnerabilities and Building Resilience; UN: New York, NY, USA, 2014. 
31. Gómez-Limón, J.A.; Riesgo, L. Alternative approaches to the construction of a composite indicator of agricultural sustainability: An application to irrigated agriculture in the Duero basin in Spain. J. Environ. Manag. 2009, 90, 3345-3362. [CrossRef] [PubMed]

32. Gebhardt, B.; Sperl, R.; Carle, R.; Müller-Maatsch, J. Assessing the sustainability of natural and artificial food colorants. J. Clean. Prod. 2020, 260, 120884. [CrossRef]

33. Shamsi, K.B.A.; Compagnoni, A.; Timpanaro, G.; Cosentino, S.L.; Guarnaccia, P. A Sustainable Organic Production Model for "Food Sovereignty" in the United Arab Emirates and Sicily-Italy. Sustainability 2018, 10, 620. [CrossRef]

34. FAO. FAO's Work on Climate Change United Nations Climate Change Conference in 2016; FAO: Rome, Italy, 2016.

35. Meuwissen, M.; Feindt, P.; Slijper, T.; Spiegel, A.; Finger, R.; de Mey, Y.; Paas, W.; Termeer, K.; Poortvliet, P.; Peneva, M.; et al. Impact of Covid-19 on farming systems in Europe through the lens of resilience thinking. Agric. Syst. 2021, 191, 103152. [CrossRef]

36. Sydorovych, O.; Wossink, A. The meaning of agricultural sustainability: Evidence from a conjoint choice survey. Agric. Syst. 2008, 98, 10-20. [CrossRef]

37. Kamali, F.P.; Borges, J.A.R.; Meuwissen, M.P.; De Boer, I.; Lansink, A.G.O. Sustainability assessment of agricultural systems: The validity of expert opinion and robustness of a multi-criteria analysis. Agric. Syst. 2017, 157, 118-128. [CrossRef]

38. Liedtke, C.; Baedeker, C.; Kolberg, S.; Lettenmeier, M. Resource intensity in global food chains: The Hot Spot Analysis. Br. Food J. 2010, 112, 1138-1159. [CrossRef]

39. Wognum, P.N.; Bremmers, H.; Trienekens, J.H.; van der Vorst, J.G.; Bloemhof, J. Systems for sustainability and transparency of food supply chains-Current status and challenges. Adv. Eng. Inform. 2011, 25, 65-76. [CrossRef]

40. Chen, C.; Chaudhary, A.; Mathys, A. Dietary Change Scenarios and Implications for Environmental, Nutrition, Human Health and Economic Dimensions of Food Sustainability. Nutrients 2019, 11, 856. [CrossRef] [PubMed]

41. Voinea, L.; Popescu, D.; Bucur, M.; Negrea, T.; Dina, R.; Enache, C. Reshaping the Traditional Pattern of Food Consumption in Romania through the Integration of Sustainable Diet Principles. A Qualitative Study. Sustainability 2020, 12, 5826. [CrossRef]

42. Haghjou, M.; Hayati, B.; Pishbahar, E. Factors Affecting Consumers' Awareness of Pesticides-Free Fruits and Vegetables BT-The Economics of Agriculture and Natural Resources: The Case of Iran; Rashidghalam, M., Ed.; Springer Singapore: Singapore, 2020; pp. 125-139. [CrossRef]

43. Galanakis, C.M. The Food Systems in the Era of the Coronavirus (COVID-19) Pandemic Crisis. Foods 2020, 9, 523. [CrossRef]

44. Brumă, I.; Vasiliu, C.; Rodino, S.; Butu, M.; Tanasă, L.; Doboș, S.; Butu, A.; Coca, O.; Stefan, G. The Behavior of Dairy Consumers in Short Food Supply Chains during COVID-19 Pandemic in Suceava Area, Romania. Sustainability 2021, 13, 3072. [CrossRef]

45. Butu, A.; Brumă, I.S.; Tanasă, L.; Rodino, S.; Vasiliu, C.D.; Doboș, S.; Butu, M. The Impact of COVID-19 Crisis upon the Consumer Buying Behavior of Fresh Vegetables Directly from Local Producers. Case Study: The Quarantined Area of Suceava County, Romania. Int. J. Environ. Res. Public Health 2020, 17, 5485. [CrossRef]

46. Chen, J.; Zhang, Y.; Zhu, S.; Liu, L. Does COVID-19 Affect the Behavior of Buying Fresh Food? Evidence from Wuhan, China. Int. J. Environ. Res. Public Health 2021, 18, 4469. [CrossRef]

47. Iocola, I.; Campanelli, G.; Diacono, M.; Leteo, F.; Montemurro, F.; Persiani, A.; Canali, S. Sustainability Assessment of Organic Vegetable Production Using a Qualitative Multi-Attribute Model. Sustainability 2018, 10, 3820. [CrossRef]

48. De Olde, E.M.; Oudshoorn, F.W.; Bokkers, E.A.M.; Stubsgaard, A.; Sørensen, C.A.G.; De Boer, I.J.M. Assessing the Sustainability Performance of Organic Farms in Denmark. Sustainability 2016, 8, 957. [CrossRef]

49. Horlings, L. The inner dimension of sustainability: Personal and cultural values. Curr. Opin. Environ. Sustain. 2015, 14, 163-169. [CrossRef]

50. Axelsson, R.; Angelstam, P.; Degerman, E.; Teitelbaum, S.; Andersson, K.; Elbakidze, M.; Drotz, M.K. Social and Cultural Sustainability: Criteria, Indicators, Verifier Variables for Measurement and Maps for Visualization to Support Planning. Ambio 2013, 42, 215-228. [CrossRef] [PubMed]

51. Chiu, R.L.H. Socio-cultural sustainability of housing: A conceptual exploration. Hous. Theory Soc. 2004, 21, 65-76. [CrossRef]

52. Scerri, A.; James, P. Accounting for sustainability: Combining qualitative and quantitative research in developing 'indicators' of sustainability. Int. J. Soc. Res. Methodol. 2010, 13, 41-53. [CrossRef]

53. Peano, C.; Migliorini, P.; Sottile, F. A methodology for the sustainability assessment of agri-food systems: An application to the Slow Food Presidia project. Ecol. Soc. 2014, 19. [CrossRef]

54. Smith, A. The Wealth of Nations/Avutia Natiunilor; Publica: Bucharest, Romania, 2011.

55. Landes, D.S. Avuția și Sărăcia Natiunilor. De ce Unele T,ări Sunt Atât de Bogate, Iar Altele atât de Sărace [The Wealth and Poverty of Nations: Why Some Are so Rich and Some so Poor]; Polirom: Iasi, Romania, 2013.

56. Acemoglu, D.; Robinson, J. De ce Eșuează Națiunile. Originile Puterii, ale Prosperității și ale Sărăciei [Why Nations Fail: The Origins of Power, Prosperity, and Poverty]; Litera: Bucharest, Romania, 2018.

57. Avram, M.; Avram, V. The Accountancy of the Tangible Assets According to the European Directives. In Proceedings of the International Conference Knowledge-Based Organization Economic Social Administrative Approaches to Knowledge-Based Organization, Sibiu, Romania, 25-27 November 2010; pp. 139-146.

58. Aleskerova, Y.; Fedoryshyna, L.; Koval, N. Features of Loan Security for the Reproduction of Fixed Assets for Agricultural Purposes. Balt. J. Econ. Stud. 2018, 4, 1-5. [CrossRef]

59. Dodor, A. Exploring Marketing Mix for Building a Viable Agro Business. Br. J. Educ. Soc. Behav. Sci. 2015, 6, 78-86. [CrossRef]

60. Maxim, A.; Străjeru, S.; Albu, C.; Sandor, M.; Mihalescu, L.; Pauliuc, S.E. Conservation of vegetable genetic diversity in Transylvania-Romania. Sci. Rep. 2020, 10, 18416. [CrossRef] [PubMed] 
61. Rubatzky, V.E.; Yamaguchi, M. World Vegetables: Principles, Production, and Nutritive Values; Springer: Boston, MA, USA, 1997. [CrossRef]

62. Masuku, M.B.; Xaba, B. Factors Affecting the Productivity and Profitability of Vegetables Production in Swaziland. J. Agric. Stud. 2013, 1, 37-52. [CrossRef]

63. Malak-Rawlikowska, A.; Majewski, E.; Wąs, A.; Borgen, S.O.; Csillag, P.; Donati, M.; Freeman, R.; Hoàng, V.; Lecoeur, J.-L.; Mancini, M.C.; et al. Measuring the Economic, Environmental, and Social Sustainability of Short Food Supply Chains. Sustainability 2019, 11, 4004. [CrossRef]

64. Binswanger, H. The Policy Response of Agriculture. World Bank Econ. Rev. 1989, 3, 231-258. [CrossRef]

65. Ulman, S.-R.; Dobay, K.-M. Environmental Protection in Romania: Perceptions versus Active Participation. Environ. Eng. Manag. J. 2020, 19, 183-194. [CrossRef]

66. Cachon, G.P.; Swinney, R. The Value of Fast Fashion: Quick Response, Enhanced Design, and Strategic Consumer Behavior. Manag. Sci. 2011, 57, 778-795. [CrossRef]

67. Kitchen, P.J.; Brignell, J.; Li, T.; Jones, G.S. The Emergence of IMC: A Theoretical Perspective. J. Advert. Res. 1999, 44, 19-30. [CrossRef]

68. Miglak-Krajewska, M.; Wojciechowska-Solis, J.; Viti, D. Consumers' Purchasing Intentions on the Legume Market as Evidence of Sustainable Behaviour. Agriculture 2020, 10, 424. [CrossRef]

69. Boca, G. Factors Influencing Consumer Behavior in Sustainable Fruit and Vegetable Consumption in Maramures County, Romania. Sustainability 2021, 13, 1812. [CrossRef]

70. Heikkilä, J. From supply to demand chain management: Efficiency and customer satisfaction. J. Oper. Manag. 2002, 20, 747-767. [CrossRef]

71. Cambra-Fierro, J.J.; Polo-Redondo, Y. Creating satisfaction in the demand-supply chain: The buyers' perspective. Supply Chain Manag. Int. J. 2008, 13, 211-224. [CrossRef]

72. Quayle, M. A study of supply chain management practice in UK industrial SMEs. Supply Chain Manag. Int. J. 2003, 8, 79-86. [CrossRef]

73. Majewski, E.; Komerska, A.; Kwiatkowski, J.; Malak-Rawlikowska, A.; Wąs, A.; Sulewski, P.; Gołaś, M.; Pogodzińska, K.; Lecoeur, J.-L.; Tocco, B.; et al. Are Short Food Supply Chains More Environmentally Sustainable than Long Chains? A Life Cycle Assessment (LCA) of the Eco-Efficiency of Food Chains in Selected EU Countries. Energies 2020, 13, 4853. [CrossRef]

74. Chiffoleau, Y.; Dourian, T. Sustainable Food Supply Chains: Is Shortening the Answer? A Literature Review for a Research and Innovation Agenda. Sustainability 2020, 12, 9831. [CrossRef]

75. Mayraz, G.; Schupp, J.; Wagner, G. Life Satisfaction and Relative Income: Perceptions and Evidence; The Institute for the Study of Labor (IZA): Bonn, Germany, 2009.

76. Wolbring, T.; Keuschnigg, M.; Negele, E. Needs, Comparisons, and Adaptation: The Importance of Relative Income for Life Satisfaction. Eur. Sociol. Rev. 2013, 29, 86-104. [CrossRef]

77. Jāhāna, S. Human Development Report 2016: Human Development for Everyone; United Nations Publications: New York, NY, USA, 2016.

78. Kowalski, S.; Veit, W. Sustainable Society Index-Your Compass To Sustainability. Available online: https://ssi.wi.th-koeln.de/ (accessed on 20 March 2021).

79. Sen, A.K. Development as Freedom; Oxford University Press: New York, NY, USA, 1999.

80. Kanbur, R.; Squire, L. The Evolution of Thinking about Poverty: Exploring the Interactions. In Frontiers of Development EconomicsThe Future Perspective; Meier, G.M., Stiglitz, J.E., Eds.; Oxford University Press: New York, NY, USA, 2001.

81. Onsrud, H.J.; Taylor \& Francis Group. Legal and Policy Paths for Effective Sustainable Development. In Development Goals Connectivity Dilemma Land and Geospatial Information for Urban and Rural Resilience; Rajabifard, A., Ed.; CRC Press: Boca Raton, FL, USA, 2020.

82. Blewitt, J. Understanding Sustainable Development; Routledge: New York, NY, USA, 2015.

83. World Bank. The Worldwide Governance Indicators (WGI). Available online: https://info.worldbank.org/governance/wgi/ (accessed on 10 November 2019).

84. Auty, R.M. How Natural Resources Affect Economic Development. Dev. Policy Rev. 2000, 18, 347-364. [CrossRef]

85. Terry, L.K. The Paradox of Plenty: Oil Booms and Petro-States; University of California Press: Berkeley, CA, USA, 1997.

86. Sachs, J.; Warner, A. Natural Resource Abundance and Economic Growth; National Bureau of Economic Research: Cambridge, MA, USA, 1995.

87. Khan, I.; Hou, F.; Le, H.P. The impact of natural resources, energy consumption, and population growth on environmental quality: Fresh evidence from the United States of America. Sci. Total. Environ. 2021, 754, 142222. [CrossRef] [PubMed]

88. Catton, W.R.; Dunlap, R.E. A New Ecological Paradigm for Post-Exuberant Sociology. Am. Behav. Sci. 1980, 24, 15-47. [CrossRef]

89. Vitousek, P.M.; Ehrlich, P.R.; Ehrlich, A.H.; Matson, P.A. Human Appropriation of the Products of Photosynthesis. BioScience 1986, 36, 368-373. [CrossRef]

90. Hinrichs, R.A.; Kleinbach, M. Energy: Its Use and the Environment; Cole Cengage Learning: Boston, MA, USA, 2012.

91. Hill, R.; O'Keefe, P.; Snape, C. The Future of Energy Use; Earthscan Publications Ltd.: London, UK, 1995. 
92. Adegbeye, M.; Reddy, P.R.K.; Obaisi, A.; Elghandour, M.; Oyebamiji, K.; Salem, A.; Morakinyo-Fasipe, O.; Cipriano-Salazar, M.; Camacho-Díaz, L. Sustainable agriculture options for production, greenhouse gasses and pollution alleviation, and nutrient recycling in emerging and transitional nations-An overview. J. Clean. Prod. 2020, 242, 118319. [CrossRef]

93. Brieger, S.A. Social Identity and Environmental Concern: The Importance of Contextual Effects. Environ. Behav. $2019,51,828-855$. [CrossRef]

94. Diekmann, A.; Franzen, A. Environmental Concern: A Global Perspective. In Einstellungen und Verhalten in der empirischen Sozialforschung; Springer Science and Business Media LLC: Berlin, Germany, 2019; pp. 253-272.

95. Dunlap, R.E.; Scarce, R. Poll Trends: Environmental Problems and Protection. Public Opin. Q. 1991, 55, 651-672. [CrossRef]

96. Dunlap, R.E.; York, R. The Globalization of Environmental Concern and The Limits of The Postmaterialist Values Explanation: Evidence from Four Multinational Surveys. Sociol. Q. 2008, 49, 529-563. [CrossRef]

97. Gatti, R.C. Trends in human development and environmental protection. Int. J. Environ. Stud. 2016, 73, 268-276. [CrossRef]

98. Inglehart, R. Public Support for Environmental Protection: Objective Problems and Subjective Values in 43 Societies. PS Polit. Sci. Polit. 1995, 28, 57. [CrossRef]

99. Kemmelmeier, M.; Król, G.; Kim, Y.H. Values, Economics, and Proenvironmental Attitudes in 22 Societies. Cross-Cultural Res. 2002, 36, 256-285. [CrossRef]

100. Poortinga, W.; Steg, L.; Vlek, C. Values, Environmental Concern, and Environmental Behavior: A Study into Household Energy Use. Environ. Behav. 2004, 36, 70-93. [CrossRef]

101. Sneddon, C.; Howarth, R.; Norgaard, R.B. Sustainable development in a post-Brundtland world. Ecol. Econ. 2006, 57, 253-268. [CrossRef]

102. Cross, P.; Edwards, R.T.; Hounsome, B.; Edwards-Jones, G. Comparative assessment of migrant farm worker health in conventional and organic horticultural systems in the United Kingdom. Sci. Total. Environ. 2008, 391, 55-65. [CrossRef]

103. Tudor, M.M. Factorii Rezilientei Economico-Sociale în Spatiul Rural Românesc [Factors of Socio-Economic Resilience in the Romanian Rural Area]; Romanian Academy Publishing House: Bucharest, Romania, 2017.

104. Hurduzeu, G.; Kevorchian, C.; Gavrilescu, C.; Hurduzeu, R. Hazards and Risks in the Romanian Agriculture Due to Climate Changes. Proc. Econ. Financ. 2014, 8, 346-352. [CrossRef]

105. Ladaru, G.-R.; Ilie, D.; Diaconeasa, M.; Petre, I.; Marin, F.; Lazar, V. Influencing Factors of a Sustainable Vegetable Choice. The Romanian Consumers' Case. Sustainability 2020, 12, 9991. [CrossRef]

106. Dunlap, R.E.; Jones, R.E. Environmental Concern: Conceptual and Measurement Issues. In Handbook of Environmental Sociology; Greenwood Press: Westport, CT, USA, 2002; pp. 482-524.

107. Litchfield, P.; Cooper, C.; Hancock, C.; Watt, P. Work and Wellbeing in the 21st Century. Int. J. Environ. Res. Public Health 2016, 13, 1065. [CrossRef]

108. Cooper, C.L.; Flint-Taylor, J.; Pearn, M. Building Resilience for Success; Palgrave Macmillan: London, UK, 2013. [CrossRef]

109. Pham, P.; Radhakrishnan, B.; Thiagarajah, J.; Ratnavale, D.; Samarasinghe, S.; Vinck, P. Challenges in Attaining Durable Solutions for Resettled Female-Headed Households in Vavuniya, Sri Lanka. J. Peacebuild. Dev. 2018, 13, 111-115. [CrossRef]

110. Maican, S.; Muntean, A.; Paștiu, C.; Stępień, S.; Polcyn, J.; Dobra, I.; Dârja, M.; Moisă, C. Motivational Factors, Job Satisfaction, and Economic Performance in Romanian Small Farms. Sustainability 2021, 13, 5832. [CrossRef]

111. Sabates-Wheeler, R. Farm Strategy, Self-Selection and Productivity: Can Small Farming Groups Offer Production Benefits to Farmers in Post-Socialist Romania? World Dev. 2002, 30, 1737-1753. [CrossRef]

112. Ghib, M.L.; Larkham, K.; Wavresky, P.; Luca, L. Small Farm in Romania: Evolution under Localization Constraint? In Proceedings of the 111 EAAE-IAAE Seminar: Small Farms: Decline or Persistence? Canterbury, UK, 26-27 June 2009.

113. Joshi, P.K.; Joshi, L.; Birthal, P.S. Diversification and Its Impact on Smallholders: Evidence from a Study on Vegetable Production. Agric. Econ. Res. Rev. 2006, 19, 219-236.

114. Ulman, S.-R. Study on General Awareness Regarding the Problem of Environmental Degradation. CES Work. Pap. 2018, 10, 1-26.

115. National Institute of Statistics. AGR108A-Area Cultivated with Main Crops by Ownership Form, Macroregions, Development Regions and Counties. Available online: http://statistici.insse.ro:8077/tempo-online/\#/pages/tables/insse-table (accessed on 1 May 2021).

116. USAMV. Raport Final de Cercetare la Proiectul PRODLECO "Evaluarea Stadiului Actual și a Potenţialului de Micole Ecologice în Zona de Nord-Est a României" [Final Research Report on the PRODLECO Project "Assessment of the Current State and Development Potential of Organic Vegetable Production in NOrtheastern Romania"]; USAMV: Iasi, Romania, 2008. Available online: https: //www.uaiasi.ro/CEEXURI/PRODLECO/Raport_final.pdf (accessed on 1 November 2020).

117. Brumă, I.S. Economia Producţiei de Legume Ecologice în Moldova. Cercetare Tematică [Economy of Organic Vegetable Production in Moldova. Thematic Research]; Terra Nostra Iași: Iasi, Romania, 2013.

118. Organisation for Economic Co-Operation and Development. Guidelines on Measuring the Quality of the Working Environment; OECD: Paris, France, 2017. [CrossRef]

119. Abdi, H.; Valentin, D. Multiple Correspondence Analysis. In Encyclopedia of Measurement and Statistics; SAGE Publications Inc.: Thousand Oaks, CA, USA, 2007.

120. Di Franco, G. Multiple correspondence analysis: One only or several techniques? Qual. Quant. 2016, 50, 1299-1315. [CrossRef]

121. Pedersen, M. A Career Is Nothing Without a Personal Life: On the Social Machine in the Call for Authentic Employees. Ephemer. Theory Polit. Organ. 2011, 11, 63-77. 
122. Costea, B.; Crump, N.J.; Amiridis, K. Managerialism and "Infinite Human Resourcefulness": A Commentary on the "Therapeutic Habitus", "Derecognition of Finitude" and the Modern Sense of Self. J. Cult. Res. 2007, 11, 245-264. [CrossRef]

123. Fleming, P. Authenticity and the Cultural Politics of Work: New Forms of Informal Control; Oxford University Press: Oxford, NY, USA, 2009.

124. Bohatereț, V.M.; Brumă, I.S. Tipologia exploataților agricole în Regiunea de Dezvoltare Nord Est a Românie. In Studii și Cercetări de Economie Rurală [Typology of Agricultural Holdings in the North East Development Region of Romania. In Studies and Researches of Rural Economy]; Bohateret, V.M., Ed.; Terra Nostra Iași: Iași, Romania; pp. 184-261.

125. Butu, A.; Vasiliu, C.D.; Rodino, S.; Brumă, I.-S.; Tanasă, L.; Butu, M. The Process of Ethnocentralizing the Concept of Ecological Agroalimentary Products for the Romanian Urban Consumer. Sustainability 2019, 11, 6226. [CrossRef]

126. Butu, A.; Vasiliu, C.D.; Rodino, S.; Brumă, I.-S.; Tanasă, L.; Butu, M. The Anthropological Analysis of the Key Determinants on the Purchase Decision Taken by the Romanian Consumers Regarding the Ecological Agroalimentary Products. Sustainability 2019, 11, 4897. [CrossRef] 